\title{
Trafik Güvenliği Kurallarının ve İşaretlerinin Eğitimi için Etkileşimli 3B Sanal Ortam Araştırma Makalesi/Research Article
}

\author{
Tarı İÇTEN \\ Milli Eğitim Bakanlı̆̆ı, Giresun, Türkiye \\ ictentarik@gmail.com \\ (Geliş/Received:07.09.2020; Kabul/Accepted:05.04.2021) \\ DOI: $10.17671 /$ gazibtd.791458
}

\begin{abstract}
Özet-Sanal ortamlar gerçek dünya riskleri olmadan, herhangi bir ek maliyet oluşturmadan, karmaşık problemler ile uğraşmadan yenilikçi ve eğlenceli firsatlar sunmaktadır. Bu firsatların en önemlisi yenilikçi öğrenme ortamları ve bu ortamlardaki güvenlik eğitimidir. Birçok çalışma, trafik kazalarının ana nedeni olarak trafik güvenlik eğitiminin eksikliğini bildirmektedir. Bu kazaların nedenleri arasında, yol kullanıcısı olan yayaların/sürücü adaylarının trafik kurallarını doğal bir davranış biçimine getirmemesi gösterilmiştir. Bu çalışmada, yayaların/sürücü adaylarının trafikte karşılaşacakları sorunların çözümünde ve giderilmesinde sanal ortamların bir çözüm aracı olup olmadığının belirlenmesine yönelik bir araştırma yürütülmüştür. Bu çalışmanın amacı, yayaların/sürücü adayların gerçek trafik kurallarını temel alan sanal bir ortamda trafik kurallarını öğrenebilmeleri için eğitim amaçlı sanal bir ortam tasarlamaktır. Bu ortam doğal el hareketlerinin izlendiği ve araçların zekice hareket ettiği yeni bir yaklaşımı temel almaktadır. Araştırmanın değerlendirilmesinde; Başarı Testi ve Buradalık Anketi ve Katılımcı Görüş Formu kullanılmıştır. Başarı testi puanları; uygulama aracının etki büyüklüğünün büyük düzeyde olduğunu (Cohen's $\mathrm{d}=1,29>, 80)$ ve katılımcı başarısına pozitif yönde katkı sağladığını göstermiştir. Ayrıca Buradalık Anketinde; katılımcıların sanal trafik senaryosunun içindeymiş gibi hissetme duygusunu yaşadıkları belirlenmiştir. Sonuçlar temassız hareket izleme arayüzünün ve sanal ortamların etkili bir eğitim aracı olarak kullanılabileceğini göstermiştir.
\end{abstract}

Anahtar Kelimeler — sanal ortam, leap motion, trafik eğitimi, sanal gerçeklik

\section{Interactive 3D Virtual Environment for Learning Traffic Safety Rules and Signs}

\begin{abstract}
Virtual environments offer innovative and fun opportunities without real-world risks, creating any additional costs, and dealing with complex problems. The most important of these opportunities are innovative learning environments and safety training in these environments. Many studies report the lack of traffic safety education as the main cause of traffic accidents. Among the reasons for these accidents, it has been shown that pedestrians/driver candidates who are road users do not bring the traffic rules to a natural way of behavior. In this study, research was conducted to determine whether virtual environments are a solution tool in solving and troubleshooting the problems that pedestrians/driver candidates will encounter in traffic. The purpose of this study is to design a virtual environment for educational purposes so that pedestrians/driver candidates can learn traffic rules in a virtual environment based on real traffic rules. This environment is based on a new approach in which natural hand movements are followed and vehicles move intelligently. In the evaluation of the research, The Achievement Test and the Presence Questionnaire and Participant Opinion Form were used. Achievement test scores; showed that the effect size of the implementation tool was large (Cohen's $d=1.29>.80$ ) and positively contributed to participant success. Also in the Presence Questionnaire, It was determined that the participants experienced the feeling of being in the virtual traffic scenario. The results showed that the contactless motion tracking interface and virtual environments can be used as an effective training tool.
\end{abstract}

Keywords - virtual environment, leap motion, traffic education, virtual reality 


\section{GİRIŞ (INTRODUCTION)}

Trafik Güvenliği Eğitimi; yasal koşulların belirlediği trafik kurallarını, kişinin yaşantısı sırasında doğal davranışlar şekline dönüştürebilmek, kişilerin can ve mal güvenliğini sağlamak için yapılması gereken çalışmaların tümüdür [1]. Bu eğitimlerin yetersizliği kazalara, sürücü ve yayaların ciddi yaralanmalarına hatta ölümlerine sebep olmaktadır. Dünya çapında her yıl 1,2 milyon insan trafik kazalarında hayatını kaybetmekte ve 50 milyon kadar insan yaralanmaktadır [2]. Dünya çapında trafik kazaları tüm ölümlerin yüzde 2,1'ini oluşturmaktadır [2]. Bu kazalarının yüzde 95'i insan kaynaklıdır [3]. Yol kullanıcısı olan yayaların ve sürücü adaylarının trafik kurallarını doğal davranışlar haline getirmemesi, trafik kurallarını bilmemesi ve buna bağlı karar verme hataları insan kaynaklı [4] hataların başında gelmektedir. Trafik kazalarının önlenmesinde öncelikle mevcut yasadaki sorunlar tespit edilmeli ve trafik güvenliği eğitimleri yeni nesil eğitim yaklaşımları [5] ile çözümlenmelidir. Günümüzde yeni nesil eğitim yaklaşımını temel alan sanal ortamlar yol kullanıcısı olan yayaların/sürücü adaylarının trafik kurallarını öğrenmelerini sağlayabilir ve kazaların önüne geçilmesinde etkili bir çözüm olabilir. Trafik güvenlik eğitimleri eğlenceli, etkili ve öğrenmeyi merkeze alan eğitsel sanal gerçeklik oyun ortamları olarak geliştirilebilir. $\mathrm{Bu}$ ciddi oyun ortamları yayaların ve sürücü adaylarının doğru ve güvenli davranış modellerini öğrenmelerini, bunları benimseyip hayat tarzı haline getirmelerini sağlayabilir [1]. $\mathrm{Bu}$ nedenle trafik kurallarının eğitimi için sanal ortamların eğitsel amaçlı kullanılması önemlidir. Eğitsel sanal ortam performans kriterlerini; eğitsel oyun yaklaşımı, etkileşim yöntemi, görüntüleme aracı direkt olarak etkilemektedir.

Geleneksel oyunların en önemli eksikliği sınırlı etkileşimdir. İyi tasarlanmış bir oyun ve bu oyunun içeriğinin amacı oynanan sürede kullanıcının geçirdiği zamandan zevk almasını sağlayarak etkileşimini sürdürülebilir biçimde uzatmaktır [6]. Aynı zamanda oyuncu olmayan karakterlerin (Non Player Character, NPC) zekice hareket etmesini sağlamaktır. Oyunlaştırma (gamification), kullanıcı deneyimini ve kullanıcı etkileşimini geliştirmek ve oyun mekaniklerinin oyun-dış1 alanlardaki motivasyonu arttırmak amacıyla kullanılan bir yaklaşımdır [7]. Bu yaklaşımı temel almayan sanal eğitim oyunlarının etkinliği ve öğreticiliği eksik kalmaktadır. Bilişsel becerinin gelişmesini engellemektedir. Yetişkinler, çocuk ve gençlere göre daha gerçekçidir ve gördükleri eğitimin ihtiyaçlarına somut çözümler getirmesini beklerler [8]. Bu beklenti ciddi oyun ortamlarının gerçek hayatta bir amaç (eğitim, sağlık) için kullanılabilmesindendir. Amacı, hedefi ve etkinlik döngüleri eksik kalmış bir sanal ortam eğitiminde istenen davranışsal çıktılar gözlenemez [9]. Başarılı bir sanal eğitim ortamı için amaç net bir şekilde ifade edilmeli, uygun bir oyun motoru seçilmeli, sanal çevre iyi modellenmeli, sürükleyici ve gerçekçi bir VR görüntüleme aracı kullanılmalıdır.
Uygun bir oyun motoru kullanıcısına çapraz platform desteği (Cross-Platform), kullanıcı arayüzü (UI), kullanıcı deneyimi (UX) gibi avantajlar sağlamaktadır ve sanal eğitim ortamlarının kalitesini artırmaktadır. Sanal eğitim ortamı, sınıfın veya laboratuvarın/çevrenin oyun motorları ile benzetiminin yapılmasıdır [10]. Bu ortamının gerçek dünyadan soyutlanması, kullanıcının tamamen sanal dünyanın bir parçası haline getirilmesi gereklidir. Sanal Gerçeklik (virtual reality, VR) olarak ifade edilen bu kavram, farklı teknolojiler kullanarak oluşturulan bilişim tabanl1, çok boyutlu ortamlardır. VR ile oluşturulan ortamlar (I3); daldırma (immersion), etkileşim (interaction) ve hayal gücü (imagination) gibi bileşenlere sahiptir [11]. Bu bileşenleri içeren VR sistemler ses ve görüntüyle kuşatma ve daldırma, sürükleyici deneyim ve gerçek zamanlı etkileşim gibi yeteneklere sahiptir [12]. $\mathrm{Bu}$ yetenekler geleneksel eğitimlerde gerçek anlamda hissedilememektedir. Etkileşim, sistemle iletişim kurmak için bir araçtır. Fare, klavye veya tuş takımı gibi tek boyutlu (1B) veya iki boyutlu (2B) ortamları kullanan geleneksel insan-bilgisayar etkileşiminin aksine, VR' deki etkileşim genellikle üç boyutlu (3B) ortamda gerçekleştirilir [13]. Bu nedenle doğru VR gözlük kullanımı; VR ortamın çözünürlüğü, dokunsal etkileşimi ve gerçekliği için önemlidir.

Valve Index, Oculus Quest, Oculus Rift, Sony PlayStation VR, Samsung Gear VR, Sony Morpheus, HTC Vive gibi görüntüleme araçları en çok tercih edilen VR gözlükleridir. Günümüzde bu gözlükler; eğitim, sağlık, eğlence vb. alanlarda $3 \mathrm{~B}$ ortamın görüntülenmesi ve etkileşimi için kullanılmaktadır. Sanal ortam üzerine yapılmış $1 \mathrm{~B}$ ve $2 \mathrm{~B}$ sistemlerin en önemli dezavantajı kullanıcılarına sınırlı etkileşim ve daldırma eksikliği sunmalarıdır. Buna karşın gözü kaplayan VR gözlük kullanımı kullanıcının dünya ile bağlantısını kesmesi, kullanıcıyı tamamen sanal dünyanın bir parçası haline getirmesi ve kullanıcıya sürükleyici bir deneyim yaşatması konusunda başarılıdır. Kullanıcının sanal ortamda verdiği tüm tepkiler sanal ortam tarafından karşılanmalıdır. $\mathrm{Bu}$ anlamda sanal ortamın tasarımcı tarafından kusursuz bir şekilde tasarlanması gereklidir [14]. Bu bağlamda başarılı bir tasarım güçlü "gerçeklik hissi" oluşturmakta iken, kusurlu bir tasarım kullanıcı tarafında zayıf "gerçeklik hissi" olarak algılanmaktadır. Ayrıca kullanılan teknolojiyi zayıflatmaktadır. Yapılan araştırmalar [15] gözü kaplayan VR gözlüklerinin kullanıcılara güçlü ve sürükleyici bir deneyim yaşattığını göstermektedir.

Açıklanan gerekliliklerin dikkate alındığı bu çalışmada, yayaların ve sürücü adaylarının trafikte karşılaşacakları sorunların bulunmasında ve giderilmesinde sanal ortamların çözüm olup olmadığının belirlenmesine yönelik bir araştırma yürütülmüştür. Amaç, yayaların ve sürücü adaylarının trafik kurallarını ve işaretlerini öğrenebilmeleri için etkileşimli 3B eğitim ortamı tasarlamaktır. Trafik kurallarının geniş içerikli olması sebebiyle bu çalışmada kavşaklarda geçiş hakkı, araç geçiş üstünlükleri, trafik işaret levhaları ve karşıdan karşıya geçme kuralları ele alınmıştır. Bu farklı kuralların 
sanal ortamda farklı senaryolar şeklinde tasarlanması gereklidir. $\mathrm{Bu}$ nedenle; ele alınan kurallar çerçevesinde üretilecek senaryoların bir kısmı soru/cevap seçimi sonrası benzetim gösterimi, bir kısmı kullanıcı görevleri, bir kısmı doğru/yanlış seçimi şeklinde planlanmıştır. Bu plan çerçevesinde kullanıcı arayüzünün sol üst kısımda, kullanıcının senaryo noktalarını bulabilmesini sağlayacak küçültülmüş soru haritasına (mini-map) sahip bir üstten görünüm oluşturulmuştur. Gezinme ve dokunma işlemleri için VR gözlüğü ile uyumlu temassız kullanılabilen el takip cihazı (Leap Motion) kullanılmıştır. Araç hareketleri için oyun mekaniğine sahip oyun algoritması geliştirilmiştir. $\mathrm{Bu}$ sayede kullanıcılar trafik kurallarını 1B-2B yerine 3B VR gözlük ile etkileşimli ve uygulamalı öğrenme imkânına sahip olmuşlardır.

\section{2. İLGILI ÇALIŞMALAR (RELATED WORKS)}

Yapılan alanyazın taramasında trafik kuralları eğitiminde yapılan çalışmaların büyük bir çoğunluğunun artırılmış gerçeklik (augmented reality, AR) ve VR teknolojilerini temel aldığ 1 tespit edilmiştir. Bunlardan VR teknolojisini temel alan çalışmaların bir kısmı, bu çalışmanın dışında bırakılan simülatör araçlarının kullanıldığı direksiyon eğitimi, sürüş eğitimi ve sürücü eğitimi olduğu, diğer bir kısmının ise bu çalışmanın konusu olan VR cihazlarının kullanıldığı, katılımcılara trafik işaretlerinin veya yaya eğitimlerinin verildiği çalışmalar olduğu tespit edilmiştir.

Alanyazında VR eğitimlerin yayaların yaya geçiş eğitimine etkisinin araştırıldı ̆̆ çalışmalardan bir kısmı şu şekildedir: Tzanavari ve ark. (2014) [16], 9-10 yaşlarındaki çocukların yol geçiş performanslarını etkileyen faktörleri incelemek için sanal öğrenme uygulaması gerçekleştirmişlerdir. Uygulamanın temel amacı çocuk katılımcılara yaya kurallarını öğretmek ve karşıdan karşıya geçme becerilerini geliştirmektedir. Ayrica VR CARE (Cave Automatic Virtual Environment) aracının bir öğrenme ortamı olarak etkinliğini araştırmaktır. Araştırmada bir yaya geçidi modellenmiştir. Ortam modellemeleri için 3DS Max, animasyonlar için Autodesk Maya, etkileşim ve gezinme için Xbox kullanılmıştır. Çalışmaya rastgele seçilen 11 çocuk (4 kız ve 7 erkek ) katılmıştır. Uygulama öncesi katılımcılara özel ayakkabılar ve VR gözlükler dağıtılmıştır. Araştırmada anket, gözlem ve inceleme yapılmıştır. Sonuçlar ampirik bir değerlendirmeye tabii tutulmuştur. Bulgular; VR CARE'in bir öğrenme aracı olarak kabul edilebileceğini, sanal ortam gürültüsünün/seslerinin katılımcıların performansını etkilediğini göstermiştir. Ancak VR CARE uygulamaların maliyet sorunu, yüksek çözünürlüklü projektör gerekliliği, kurulum şartı, geniş alan ihtiyacı, el/vücut izleme zorluğu, hareket kısıtlaması gibi problemlere sahip olduğu söylenebilir. Diğer çalışmada Bart ve ark. (2008) [17], çocukların bir caddeden güvenli bir şekilde nasıl geçebileceklerini öğreten sanal bir ortamın etkinliğini değerlendirmişlerdir. Sanal ortam Superscape'in 3D Webmaster yazılımı ile 4 şeritli bir cadde olarak tasarlanmıştır. Çalışmaya 21 çocuk katılmıştır. Bulgular; deney grubundaki katılımcıların gerçek sokak geçişindeki geçiş yeteneklerinde önemli ölçüde gelişme olduğunu göstermiştir. Ancak bu çalışmada katılımcı hareketleri klavye, görüntü takibi LCD ile gerçekleştirilmiştir. Bu yöntemin HMD ve VR yapıları için uygun olmadığı söylenebilir. Çünkü kullanılan bağlantılar katılımcı hareketlerini kısıtlayabilir ve katılımcının zayıf gerçeklik hissi yaşamasına sebep olabilir. Maillot ve ark. (2017) [18] yaşlı yayaların daha güvenli yaya geçiş davranışları göstermelerine yardımcı olmak için sanal ortam eğitim programı geliştirmişlerdir. Çalışmada 20 genç (grup 1) ve 19 yaşlı (grup 2) katılımcı yer almıştır. Sistem; görüntü, ses ve hareket yakalama araçlarından oluşan tam ve küçük ölçekli simülasyon ortamlarıdır. Tam ölçekli ortam "U" şeklinde, omuz yüksekliğinde metal bir çerçeve üzerine sabitlenmiş üç adet 46 inç LCD ekrandan oluşmaktadır. Küçük ölçekli ortam tam ölçekli ortamın minyatürleştirilmiş halidir. Tam ölçekli ortam kullanıcı hareketleri ile küçük ölçekli ortam basma düğmesinin kontrol ettiği avatar hareketleri ile geçiş işlemlerini gerçekleştirmektedir. Öntest, uygulama ve sontest işlemlerinden elde edilen bulgular; büyük ölçekli VR'ın küçük ölçekli VR'a göre öğrenme etkisinin daha yüksek olduğunu göstermiştir. Ancak bu simülasyon eğitimlerinin geniş alan istemesi, fiziksel kurulum gerektirmesi ve zayıf gerçeklik hissi sunması bu çalışmanın öğreticiliğini ve kullanılabilirliğini azaltabilir. Morrongiello ve ark. (2018) [19], 7-10 yaşındaki çocukların gerçek bir ortamda "Nereden geçileceğini" ve "Nasıl geçileceğini” öğretmek için sanal bir eğitim ortamının etkinliğini araştırmışlardır. Oculus Rift ve kablosuz XBOX ONE cihazının kullanıldığı çalışmada 130 katılımcı yer almıştır. Katılımcılar deney ve kontrol grubu olmak üzere iki gruba ayrılmıştır. Bunlardan "Nasıl geçilir" niteliğindeki gruplar VR eğitimli $(\mathrm{N}=44)$ ve $\mathrm{VR}$ eğitimsiz $(\mathrm{N}=22)$; "Nereden geçilir" niteliğindeki gruplar VR eğitimli $(\mathrm{N}=43)$ ve VR eğitimsiz $(\mathrm{N}=21)$ şeklinde ayrılmıştır. Katılımcılar deney ve kontrol grubu olarak ayrılmış ve gruplara testler uygulanmıştır. Poisson ve negatif binom regresyon modelinin sonuçları; VR eğitimli grupların VR eğitimsiz gruplara göre daha başarılı olduğunu göstermiştir. Tüm bu bulgulara dayalı olarak; eğitim amaçlı sanal ortamların bireylerin davranışlarını [20], bilişsel [21] ve algısal [22] becerilerini gerçek ortama girdirmeden geliştirebilecekleri söylenebilir.

Alanyazında VR eğitimlerin özel durumları olan bireylere olan etkisinin araştırıldığı çalışmalardan bir kısmı şu şekildedir: Alanyazın araştırmaları 3B ortamların Parkinson hastalarının, görme engelli bireylerin, hiperaktivite bozukluğu olan ergenlerin ve özel eğitime ihtiyaç duyan kişilerin yaya geçiş eğitimlerinde kullanıldığını göstermiştir. Bu çalışmaların ağırlıklı olarak dokunsal ve işitsel baston gezinme uygulamaları [23], çevre hakkında faydalı bilgiler veren VR ortam araçları [24] ve Otizm Spektrum Bozukluğu olan çocuklara yönelik yapılan yaya eğitimleri [25] üzerine yapıldığı tespit edilmiştir. Bahsi konu olan çalışmaların bulguları incelendiğinde; VR ortamların özel durumu olan katılımcıların eğitimini destekleyici olmasına rağmen, bu katılımcılara yönelik geliştirilen ve gerçekten fark yaratacak sağlam ve kullanışlı VR ortamlarının oluşturulmasında önemli zorlukların bulunduğu 
saptanmıştır. Ancak bu zorluklara rağmen alanyazın taramasında kabul edilebilir başarılı bulgular verildiği birkaç çalışma tespit edilmiştir. Örneğin; Lee ve Huang (2007) [26], orta ve şiddetli derecede zihinsel engeli bulunan öğrencilerin yaya geçiş becerilerini geliştirmeye yönelik VR uygulaması geliştirmişlerdir. Araştırmada nicel araştırma yöntemlerinden tek denekli deneysel desen kullanılmıştır. Katılımcıların okula nasıl gideceklerini öğretmek için bilgisayar tabanlı, etkileşimli ve gerçek zamanlı bir yazılım uygulaması tasarlanmıştır. $\mathrm{Bu}$ tasarımda, "3D Grafik tabanlı VR" bağımsız, "yaya becerilerini geliştirme" bağımlı bir değişken olarak alınmıştır. Uygulama sonunda orta ve şiddetli zihinsel engelli katılımcıların sanal trafik ortamlarında öğrendikleri yaya becerilerini gerçek trafik ortamında da genelleyebildiklerini göstermiştir. Benzer çalışmada Clancy ve ark. (2006) [27], Dikkat Eksikliği Hiperaktivite Bozukluğu (DEHB) olan ve olmayan 48 katılımcının yol geçiş davranışını VR ortamında araştırmışlardır. Çalışma bir üniversitenin VR laboratuvarında VR gözlükler ile gerçekleştirilmiştir. Çalışmaya DEHB olan $(\mathrm{N}=24)$ ve DEHB olmayan $(\mathrm{N}=24)$ katılımcılar seçilmiştir. Katılımcılara sırayla öntest, güvenlik eğitimleri ve sontest uygulanmıştır. Çalışmanın amacı DEHB olan ve olmayan katılımcıların yol geçiş davranışlarını araştırmak olmasına karşın elde edilen bulgular VR ortamının, tehlikeli trafik davranışları gösteren katılımcıların belirlenmesinde ve eğitiminde kullanılan önemli bir araç olabileceğini göstermiştir. Diğer bir çalışmada ise Oua ve ark. (2015) [28], parkinson hastalarının yaya geçiş güvenliğini artırmak için bir eğitim programı önermişlerdir. 48 katılımcı iki gruba ayrılmıştır. Parkinson hastaları birinci grubu; normal yaşlılar ise ikinci grubu oluşturmuştur. Deney sonuçları ANOVA yöntemi ile analiz edilmiştir. Bulgular; farklı eğitim yöntemlerinin farklı sonuçlar gösterdiğini, sanal eğitim alan grubun diğer gruba göre eğitim sonunda daha iyi performans sergilediğini, parkinson hastalarının daha riskli kararlar verdiğini ancak kullanılan teknolojinin parkinson hastalarına kuralları öğrettiğini, onların özgüven becerilerini geliştirdiğini göstermiştir. Tüm bu bulgulara dayalı olarak sanal eğitim ortamlarının özel durumları olan bireylerin soyut kavramları somutlaştırmalarına ve kaygı düzeylerini azaltmalarına katkı sağladığı söylenebilir.

Alanyazında VR ortamında trafik işaretlerinin öğretildiğ $i$ ve bireylere olan etkisinin araştırıldı̆̆ çalışma sayısı oldukça azdır. Tespit edilen çalışmalardan Liu ve ark. (2010) [29], doğru ve yanlış arka plan renklerine sahip trafik işaretlerinin sunulduğu bir VR ortamı tasarlamışlardır. Çalışmanın temel amacı arka plan renkleri değiştirilmiş trafik işaretlerinin Olayla İlişkin Potansiyeller (Event-related potential) analizi kullanarak insan beynindeki bilişsel durumu incelemektir. Bulgular; VR'ın etkili bir öğrenme sağladığı göstermiştir. Lukito ve ark. (2017) [30] trafik yönetmeliği öğretiminde VR oyun eğitimlerinin etkisini araştırmışlardır. Geliştirilen çalışmadan ziyade sonuçlarının verildiği çalışmada; VR eğitimin başarıyı yüzde 20 yükselttiği belirtilmiştir. Proaño ve ark. (2019) [31] çocukların sorumlu bir yaya olmaları için trafik işaretlerinin öğretildiği ciddi 3B oyun tasarlamışlardır. Uygulama için bir kentin ölçekli model varlığı (asset) kullanılmıştır. Sistem, masaüstü bilgisayarda çalıştırılmış ve klavye ile kontrol edilmiştir. Bulgular; klavye kullanımının etkileşim ve kullanılabilirliğini zayıflattığını ancak VR eğitimlerinin katılımcıların motivasyonlarını artırdığını göstermiştir.

Sonuç olarak, alanyazında sanal ortamda yaya güvenlik eğitimlerinin verildiği ve trafik işaretlerinin öğretildiği çalışmalar olmasına rağmen sanal ortamda trafik kurallarının ve işaretlerinin birlikte uygulandığı ve öğretildiği herhangi bir çalışmayla karşılaşılmamıştır. Ayrıca bu çalışmanın geleneksel çalışmalardan en önemli fark1; mevcut çalışmalardaki gibi sadece bir yaya geçişi veya trafik işaretleri öğretimi üzerinden yayaların ve sürücü adaylarının becerilerini geliştirmek değil aynı zamanda, trafik kurallarının ve işaretlerinin öğretimi için sanal çevre özelliklerinden, VR ve el izleme araçlarının avantajlarından yararlanan bir çalışma ortaya koymaktır. $\mathrm{Bu}$ çalışma, 3B ortamda trafik kurallarının öğretildiği, araçların zekice hareket ettiği, soruların etkileşimli cevaplandığı ve sonuçlarının gerçek zamanlı değerlendirildiği yeni bir eğitim yöntemi önermektedir.

\section{TASARIM VE UYGULAMA (DESIGN AND IMPLEMENTATION)}

\subsection{Araçlar ve Yazllımlar (Tools and Software)}

$\mathrm{Bu}$ çalışmada, 3B modellemeler için 3DSMax, sanal ortam kullanımları için Unity3D (C\# dili), doğal kullanıcı arayüzü etkileşimi için Etkileşim Motoru (Interaction Engine), el takibi için Leap Motion ve VR görüntüleme sistemi için Oculus Rift kullanılmıştır. Ayrıca kullanıcı sanal ortamda bir Avatar tarafından temsil edilmiştir.

3DS Max, Autodesk tarafından geliştirilen 3B modelleme, görselleştirme ve animasyon programıdır. $\mathrm{Bu}$ çalışmada 3DS Max; araçların, trafik 1şıklarının, levhaların ve kavşakların modellenmesinde kullanılmıştır.

Unity3D, çok platformlu bir oyun motorudur. Fizik ve grafik motorları Unity3D'nin önemli parçalarıdır. Bu oyun motoru gerçek dünyada yaşanan doğal fizik olaylarının sanal ortam nesnelerine verilmesini sağlayan bir araçtır. $\mathrm{Bu}$ araç kendine özgü tümleşik bir editöre, çapraz platform desteğine, ortam gölgelemeye, script yazımına vb. birçok özelliğe sahiptir. Bu çalışmada verilen özelliklerinden ve lisans koşullarından (ücretsiz) dolayı Unity3D tercih edilmiştir.

Leap Motion Cihazı, kullanıcının el ve parmak hareketlerini benzersiz bir hassasiyetle yakalayan gerçek zamanlı optik el ve parmak takip cihazıdır. Bu cihaz, kullanıcısına hiçbir şeye dokunmadan sadece el hareketleri ile VR ortama müdahale edebilmesini (hareket, kavrama, seçme, dokunma,) sağlamaktadır. Bu çalışmada Leap Motion, Oculus Rift üzerine monte edilerek kullanılmıştır. Bu kullanım her iki elin izlenmesi ve izleme verilerinin el modeline aktarılması şeklindedir. 
Oculus Rift kullanıcının gözlerini tamamen kaplayan yeni nesil bir 3B VR gözlüğüdür. Oculus Rift bu çalışmada, geliştirilen sanal ortamı görüntülemek amaciyla kullanılmıştır.

\subsection{Sistem Tasarımı (System Design)}

Çalışmanın uygulamasına geçilmeden önce sistemin tüm işlevlerinin belirlenmesi ve tanımlanması gerekir. $\mathrm{Bu}$ kapsamda tasarıma başlamadan önce, sanal trafikte olması gereken faktörler ve en çok karıştırılan trafik kuralları ve trafik işaret levhaları sürücü kursu uzman eğitmenlerin $(\mathrm{N}=4)$ görüşleri alınarak belirlenmiştir. Uzman eğitmenlerin görüşleri dikkate alınarak belirlen faktörler şu şekildedir;

1. Senaryoların seçimi ve gerçekliği

2. Dijital araçların modellenmesi

3. Görüntüleme aracı

4. Sistem mimarisi

5. El modeli (el hareketleri ve etkileşim)

6. Kullanıcı arayüz girişi ve modülü

Birinci faktör senaryoların seçimi ve gerçekçiliğidir. Bu kısım için yetkili kurumlar tarafından hazırlanmış kavşaklarda geçiş hakkı ve geçme kurallarının anlatıldı̆̆ videolar izlenmiş, problemli alanlar belirlenmiş ve seçimler yapılmıştır. Seçim sonrası; kavşaklarda ilk geçiş hakkı kurallarını, döner kavşakta geçiş üstünlüklerini, kesişen yol üstünlüklerini ve araç takip mesafelerini içeren senaryolar soru/cevap seçimi sonrası simülasyon gösterimi şeklinde; arızalı araca gerekli trafik işaret levhalarının bırakılması ve yaya geçidinden geçiş görevlerini içeren uygulamalar kullanıcı görevleri şeklinde; trafik işaret levhalarının anlamlarını içeren sorular doğru/yanlış seçimi şeklinde hazırlanmıştır. Bu senaryoların gerçekçi bir şekilde simüle edilmesi kullanıcının güçlü daldırma hissi yaşamasını sağlayabilir. $\mathrm{Bu}$ çalışmada yer alan trafik senaryoların simülasyon şeklinde oluşturulmasının nedeni kullanıcının eylem sürecini test etmek, değerlendirmek, sonucu göstermek ve kullanıcıyı eğitmektir. Şekil 1'de $\mathrm{T}$ senaryosu ve uygulama çevresi görselli sunulmuştur.
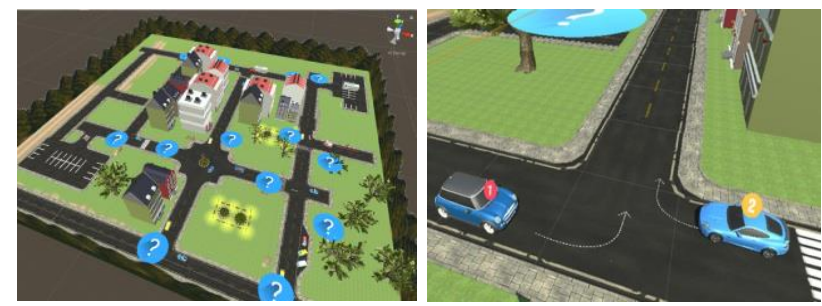

Şekil 1. Uygulama çevresi ve T senaryo

(Application environment and T scenario)

İkinci faktör yerleşkenin, araçların, işaret levhalarının modellenmesidir. Modellemede arzu edilen nesnenin gerçeğe yakın bir şekilde tasarlanması fiziksel ve matematiksel araçların kullanılmasına bağlıdır. $\mathrm{Bu}$ araçlardan birisi de Unity3D'dir. Unity3D'de bir nesne modeli; katı cisim modeli, dönüşüm modeli ve çarpışma modeli olmak üzere 3 bölümden oluşmaktadır [32]. Bu kapsamda çalışmanın katı cisim modelinin mimari bileşenleri (araçlar, yollar vb.) birbirinden bağımsız yazılımlar (Blender, Maya, Google SketchUp Pro vb.) ile modellenmiş, Photoshop ile kaplanmış ve Unity3D platformuna aktarılarak kullanılmıştır. Ancak çalışmada tasarımı zor olan bazı mimari bileşenler (insan, traktör) hazır model olarak (free3D.com, tuborsquid.com, unity varlıklar) alınmış ve 3DS Max programında düzenlenerek kullanılmıştır. Kullanıcının gerçek bir trafik ortamında olma duygusunu hissetmesi için çevre düzenlemeleri, yol çizgileri, uyarı levhaları (yol ver, girişi olmayan yol vb.) dikkatli bir şekilde modellenmiştir.

Belirlenen üçüncü olan faktör görüntüleme arac1, kullanıcıların sanal trafik çevresine dalması ve sürükleyici görsel bir deneyim yaşayabilmesi için kullanılmıştır. Bu faktör için yazılımsal ve donanımsal gereklilikler mevcuttur. Donanımsal gereklilikleri; Oculus Rift gözlüğü, Leap Motion cihazı ve HDMI çıkışı veya NVIDIA GTX kartı oluşturur. Yazılımsal ve minimum sistem gerekliliklerini; Unity 2019.4+ ve eklentileri, Win 1064 bit, Leap Motion Orion SDK ve Oculus SDK oluşturur. Çalışmanın görüntüleme sahnesi için; (a) HMD cihazına Leap Motion montaj1, (b) HMD ile Leap Motion arası konum ve yön fark dönüşümleri, (c) Leap Motion API izleme verileri erişimleri ve (d) HMD cihaz göz hizalama işlemleri yapılmıştır. Uygulama aşamasında VR gözlüğü kullanıcının gerçek dünya ile bağlantısını kopartmıştır. $\mathrm{Bu}$ kopma kullanıcının 360 derece panoramik görüş acısında yoğun grafikler ile varlık hissi yaşamasını sağlanmıştır. Ayrıca bu daldırma hissi sanal ortamdaki motor sesleri, çocuk sesleri ve korna sesleri ile güçlendirilmiştir. Şekil 2'de Oculus Rift kullanımı ve Leap Motion cihazının el modeli görseli sunulmuştur.
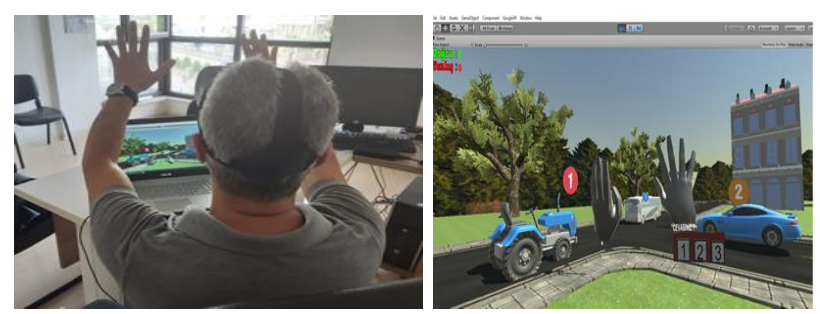

Şekil 2. Oculus Rift ve sanal ortam (Oculus Rift and VR)

Dördüncü faktör olan sistemin mimarisi 4 aşamadan oluşturulmuştur. Şekil 3'de görüleceği gibi ilk aşama, Leap Motion ile ellerin ve el hareketlerinin sezgisel ve gerçekçi bir hassasiyetle taranmasını, izlenmesini ve el modelinin Oculus Rift ekranında gösterilmesini içerir. Íkinci aşama, el hareketlerin tanımlanması ve Gezinme/Dokunma yani etkileşim işlemleridir. Bunlardan el hareketlerin tanımlanması kısmında; Statik Hareket Özellikleri (Static Gesture Features) temel alınarak komutların atanacağı fiziksel el hareketleri belirlenmiştir. Gezinme/Dokunma kısmında gezinme işlemleri için kullanıcının sol eli; kavrama, seçme ve dokunma işlemlerinde kullanıcının sağ eli referans alınmıştır. Üçüncü aşama, sanal gezinme alanının oluşturulmasıdır. Son ve dördüncü aşama ise, araç önceliklerini içeren soruların simülasyon gösterimi, yaya geçiş etkinliği 


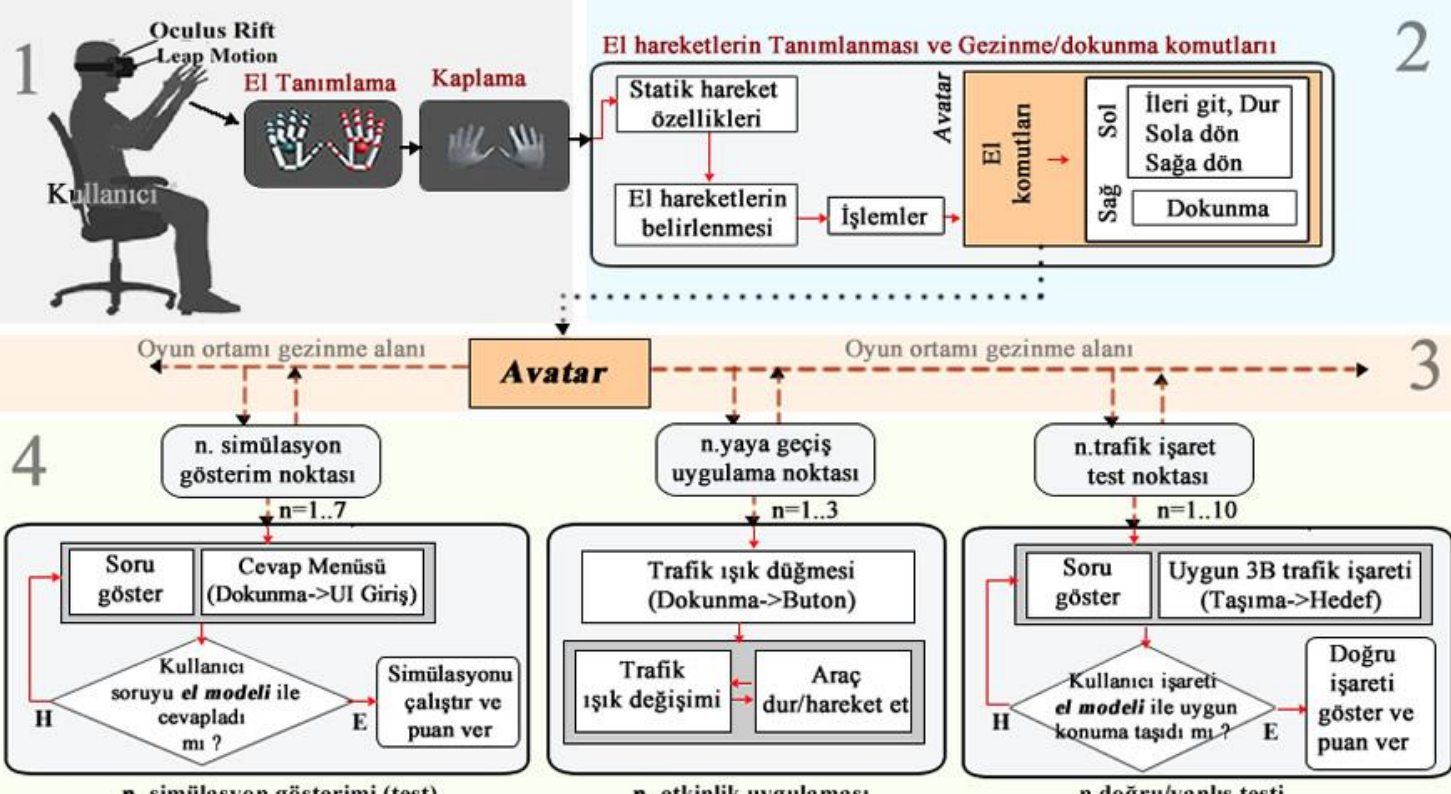

n. simülasyon gösterimi (test)

n. etkinlik uygulaması

n.doğru/yanlıs testi

Şekil 3. Sistem mimarisi (System architecture)

sorularının uygulamalı, trafik işaret levhaları sorularının doğru/yanlış seçimi şeklinde yapılmasıdır. Dördüncü aşamada belirtilen işlemler gerçek elin temsili olan el modeli ile gerçekleştirilmiştir. Makalenin ilerleyen bölümlerinde bu işlemler daha ayrıntılı olarak açıklanmıştır.

Beşinci faktör olan el modeli ise (a) El hareketleri ve (b) Etkileşimden oluşmaktadır. Çalışmada kullanılan el modeli, Leap Motion tarafindan algilanan fiziksel bir elin temsilidir. Leap Motion yazılımı (API), elin ve parmakların konumunu, yönünü ve hareketlerini tanır ve izler. $\mathrm{Bu}$ izleme ham el poz verilerinin alınması, gerçek zamanlı el modeline anlamlı bir şekilde aktarılması ve kontrol edilmesi şeklindedir. El hareketleri ise, fiziksel elin konumu ve yönüne göre el modelindeki değişikliklerdir. Genellikle el hareketlerinin (hand gesture) tanımlanmasında iki tip sinıflandırma kullanılır [33]. Bunlar: statik hareketler (static gesture) ve dinamik hareketler (dynamic gesture)'dir. [33].

(a) El hareketleri: Bu çalışmada avuç içi ve parmaklar arasındaki mesafeye göre işlem yapan statik hareket kullanımı tercih edilmiştir. Çünkü statik hareketler dinamik hareketlerden daha kolay ayırt edilebilmektedir. Statik hareket kullanımının temel amacı hareketli olmayan el pozları ile Avatarın gezinme alanında dolaşabilmesini sağlamaktır. Şekil 4'de kullanıcının sol el hareketleri ile oyun ortamında gezinebilmesini sağlayan hareket kodu verilmiştir. Bu gezinme için ilk olarak Leap Motion API'si Unity3D programına yüklenmiştir. Sonrasında bir script dosyası oluşturulmuş ve izlenen
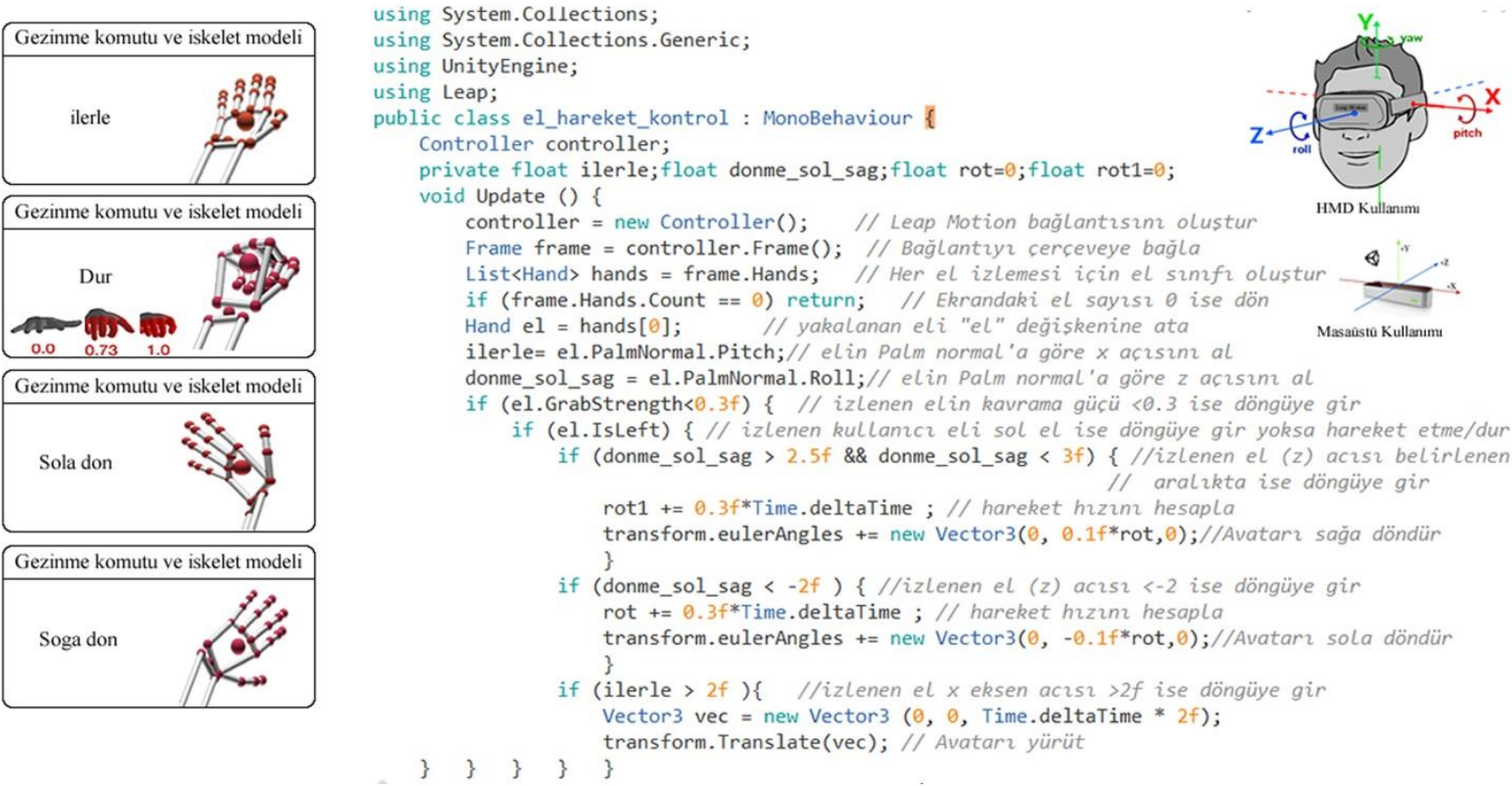

Şekil 4. Sol el veri seti ve gezinme hareketleri kodu (Left hand dataset and navigation gestures code) 
veriler upload() fonksiyonu içerisindeki Frame sınıfı nesnesi üzerinden erişilmiştir. Leap Motion bağlantısı için bir Controller nesnesi tanımlanmıștır. Controller nesnesi tarafindan alınan her veri, Frame sinıfi nesnesindeki yeni bir değişkene atanmıştır. Çünkü hareket takip işlemlerinde izlenen nesnenin anlık ve bir önceki veri setlerine ihtiyaç duyulur. Bu anlamda önceki izleme veri setine ulaşabilmek için Listener nesnesi eklenmiştir. Statik hareket dili (motion language) olarak Hand sinifi script'e tanımlanmıştır. Sonrasında sol el poz özelliklerini çıkartmak için aynı yaş grubunda rastgele 3 kişilik bir grup seçilmiştir. İnsan çalışması sonrası en uygun el pozları hareket çıkartma yöntemi ile belirlenmiştir.

Şekil 5'de sol el iskeletinden hareket çıkartma yöntemi verilmiştir. Bu yöntemdeki Palm normal (palmNormal); el avuç içi normal vektördür. Leap Motion, Unity koordinatına uyum sağlamalıdır. El düz ve açık ise bu vektör avuç içi yüzeyinden aşağı doğru bakacaktır. Palm konumu (palmPosition); el avucun merkez konumudur. Pitch açısı; elin $+\mathrm{X}$ ekseni etrafindaki dönüşüdür ve $\mathrm{YZ}$ düzlemindeki açısıdır. Yaw açısı; elin $+Y$ ekseni etrafındaki dönüşüdür ve $\mathrm{XZ}$ düzlemindeki açısıdır. Roll açısı; elin $+Z$ ekseni etrafındaki dönüşüdür ve $X Y$ düzlemindeki açısıdır.

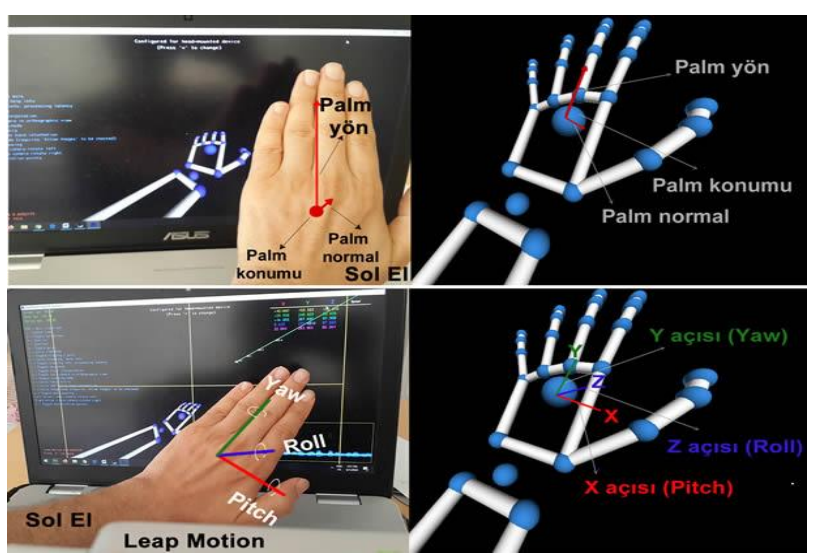

Şekil 5. Sol el iskeletinden gezinme hareketi çıkartma (Extracting navigation gestures from the left hand skeleton)

Hareket çıkartma yöntemi kullanılarak elde edilen en uygun sol el pozları, komutları ve görevleri Şekil 6'da sunulmuştur. Gezinme hareketleri kod yapısında (Şekil 4) bu hareketlerden ilerle için Pitch vektör sınıfı, Dur için GrapStrength parametresi, sağa dönme veya sola dönme için Roll vektör sınıfı tanımlanmış ve değişkenlere atanmıştır. Bu değişkenlerin vektör ve parametre değerleri üzerinden yine aynı grup ile deneme çalışmaları yapılmış, en uygun eşik değerleri tespit edilmiştir. Son aşamada ise hareket çıkartma yöntemi ile belirlenen ilerle, dur, sola don, saga don gezinme hareketleri ve eşik değerleri Şekil 4'de görüleceği gibi Hand sınıfı üzerinden sol elin tespit edilmesi (IsLeft) koşuluna bağlanmıştır.

b) Etkileşim: Etkileşim nesneleri kısımda el çarpışma (hand collision) davranışı için Etkileşim Motoru (Interaction Engine 1.2.0) kullanılmıştır. Bu motorun temel amacı, kullanıcının oyun nesneleriyle (seçim butonu) doğru bir şekilde etkileşime girmesini sağlamaktır. $\mathrm{Bu}$ etkileşim kullanıcının VR ortamındaki oyun nesnelerini kavraması, seçmesi ve dokunması şeklindedir. Seçme işlemine, geçiş önceliği içeren sorulardaki doğru seçeneği tıklama; dokunma işlemine, yaya geçişindeki trafik 1şık değişim düğmesine dokunarak yeşil 1şık yakma; kavrama işlemine, arızalı bir aracın arkasına bir reflektör modelini bırakma örnek verilebilir. $\mathrm{Bu}$ etkileşimler Şekil 7'de sunulmuştur. Çalışmada yer alan oyun nesnelerine etkileşim yeteneği kazandırmak için üç temel işlem yapılmıştır. Bunlar sırasıyla; uygulamaya Interaction Engine' in yüklenmesi, Interaction Manager'in Hierarchy'e ve Interaction Hand'in el modeline component olarak dâhil edilmesi, oyun nesnelerine etkileşim davranışı veren InteractionBehaviour script'inin component olarak eklenmesi ve sağ elin izlenmesidir.

Şekil 7'de sırasıyla; kavrama, seçme ve dokunma etkileşimleri sunulmuştur. Bu etkileşimler kullanıcının sağ el hareketini taklit eden sağ el modeli ile gerçekleştirilmiştir. Örneğin kullanıcının bir caddeden karşıya geçmesi için birkaç eylemi gerçekleştirmelidir. İlk olarak, kaldırıma yaklaşmalı yaklaşan aracı ve yeşil ışı̆̆ı kontrol etmelidir. Yeşil 1 şı yandığında veya sağ el ile 1şığ1 yaktığında karşıya geçmelidir. Trafik 1şığı olmadığ durumda ise trafikteki en uygun anı değerlendirmeli ve karşıya geçilmelidir. $\mathrm{Bu}$ işlemler sırasında kullanıcının hatalı geçiş davranışı (kırmız 1şık, araba teması) göstermesi; araçlar ve trafik 1şıkları ile ilişkilendirilmiş çarpışma kontrol nesneleri (raycasthit, collider) üzerinden alınmıştır ve puanlanmıştır.

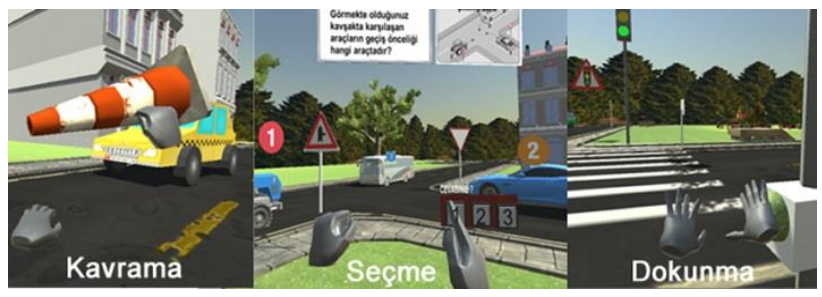

Şekil 7. Sağ el ile kavrama, seçme ve dokunma (Holding, selection and touch with the right hand)

\begin{tabular}{|c|l|l|c|l|l|}
\hline Komut & \multicolumn{1}{|c|}{ Sol El Hareketi } & \multicolumn{1}{|c|}{ Görev (Avatar) } & Komut & \multicolumn{1}{|c|}{ Sol El Hareketi } & \multicolumn{1}{c|}{ Görev (Avatar) } \\
\hline (a) & Sol eli ileriye uzatma & İleriye doğru hareket et & (d) & Sol eli hafif sağa eğme & Sağa doğru ilerle \\
\hline (b) & Sol eli hafif sola eğme & Sola doğru ilerle & (e) & Sol eli tam sağa eğme & Olduğu yerde sağa dön \\
\hline (c) & Sol eli tam sola eğme & Olduğı yerde sola dön & (f) & Sol eli yumruk yapma & Dur \\
\hline & & & &
\end{tabular}

Şekil 6. Gezinme komutları ve el hareketlerinin belirlenmesi (Navigation commands and determination of hand navigation gestures) 
Altıncı faktör doğal kullanıcı arayüzü giriş modülü, el modeli ile sanal ortamdaki olay nesnelerini (akış işlemleri) tetiklemek için kullanılmıştır. $\mathrm{Bu}$ modül, kendisine verilen görevleri alır ve istenen bileşenlere gönderir. Günümüzde geleneksel ve en çok kullanılan giriş modülü dokunmatik ekran giriş modülü olarak söylenebilir. Ancak bu modül Oculus Rift gibi araçlar için pek uygun değildir. Çünkü Oculus Rift kullanıcısı ekran üzerindeki seçeneklere erişemez ve dokunamaz. Bu nedenle bu çalışma için fiziksel olarak etkileşime giren dokunsal bir 3B sanal UI giriş modülü geliştirilmiştir. Bu modülün amacı kullanıcının trafik geçiş üstünlükleri ve trafik işaret levhaları konularını içeren soruları dokunsal olarak cevaplamasını sağlamaktır. Ayrıca bu dokunsal etkileşim o anki bağlı olduğu trafik senaryosunun çalıştırılması ve puan toplanması gibi olayları da tetiklemektedir. Dokunsal etkileşim doğal ve sezgisel bir kullanım için önemlidir. İyi bir UI giriş modülü dikkatli bir şekilde tasarlanmalıdır. $\mathrm{Bu}$ çalışmadaki UI giriş modülü tasarımı sürecinde üç önemli konu dikkate alınmıştır. Bunlardan birincisi; VR başlığı ve kullanıcı eli arasındaki mesafenin uygunluğudur. Bu durum çalışmada en uygun derinlik algısı (depth perception) ile çözümlenmiştir. İkincisi; UI giriş modülünün nasıl gösterileceğidir. Bu durum çalışmada ölçek faktörünün (scale factor) belirlenmesiyle çözümlenmiştir. Üçüncüsü ise; dinamik geri bildirim yapısıdır. Bu durum çalışmada giriş modülünün dokunmatik UI düğmesi olarak tasarlanmasıyla çözümlenmiştir.

\subsection{Yapay Zekâ Tekniklerinin Uygulanması (Application of AI Techniques)}

Bu kısım; (a) Araç (araba) hareketleri, (b) Çarpışma kontrolleri ve (c) Trafik ışık durumları olmak üzere üç kısımdan oluşmuştur.

(a) Araç Hareketleri: Çalışmadaki oyuncu olmayan karakterlerden (Non Player Character) araç hareketleri, akıllı bir oyun trafik sistemini içerir. Sistem, kullanıcıdan gelen girdilere yanıt vermek ve oyundaki araçların belirli olayların gerçekleşmesi durumunda yol bulma algoritmasına (bir noktadan diğerine) göre hareket etmek amacıyla kullanılmıştır. Çünkü kullanıcının trafik sorularını okuyabilmesi, dokunsal cevap verebilmesi ve sonrasında ilgili doğru trafik simülasyonunu oynatılmas gerekir. $\mathrm{Bu}$ önemli durum için Unity3D navigasyon aracı NavMesh (Navigasyon Mesh) kullanılmıştır. Ancak NavMesh kullanımı tek başına güven vermez [34]. Çünkü NavMesh yapılı Yapay Zekâ-YZ (Artificial Intelligence, AI) araçları diğer araçlarla arasındaki mesafeyi koruyamama, hız sınırını aşma, yaya geçiş uygulamalarında yayalara çarpma ve kırmızı 1şıkta geçme gibi istenmeyen davranışlar sergileyebilir. $\mathrm{Bu}$ olumsuzlukların çözümü için araç hareket yapısına raycasting kullanımını içeren çarpışma kontrolleri eklenmiştir. $\mathrm{Bu}$ nedenle çalışmada araç hareketleri ve çarpışma kontrolleri yapılarını temel alan Oyun Yapay Zekâ (Game AI) algoritması geliştirilmiştir. Şekil 8'de geliştirilen algoritmanın araç geçiş üstünlüğü ( $\mathrm{T}$ kavşak senaryosu) senaryosundaki işlem adımları verilmiştir.
Şekil 9'da ise geliştirilen YZ algoritmasının kod yapısı sunulmuştur. $\mathrm{Bu}$ algoritmada kullanılan bazı değişkenlerin, komutların ve sınıfların açıklamaları aşağıdaki gibidir:

- soru1: soru1'e ait simülasyon script'i

- durum: soru (canvas) ve menü (UI) gösterimi (bool)

- UI: dokunsal kullanıcı cevap menüsü

- SetActive: etkinleştirme/devre dışı bırakma

- deger: kullanici cevabi (int)

- canvas: kullanıcı arayüz ekranı

- aktif: görünürlük değişkeni (bool)

- yanliş, dogru: doğru/yanlış cevap sayısı

- kapsul: avatar tarafından ilgili sorunun gösterilmesini sağlayan senaryo noktası

- engel: araçların durmasını sağlayan nesne (isik_bariyer)

- $y a z:$ metin değişkeni (string)

- oynat: simülasyon oynatımı

- UI_cevap: el modeli, UI tıklama değeri (int)

- yolTakipNesnesi Araç yol takip nesnesi (nav0,nav1,nav2...navn),

- yolTakipNesnesiSayisi: yolTakipNesnesi (nav0,nav1,nav2...navn) sayısı (int)

- nav: ajan nesnesi (NavMeshAgent)

- mesafe: araç - yolTakipNesnesi mesafesi

- hit: çarpışma değişkeni (raycasthit)

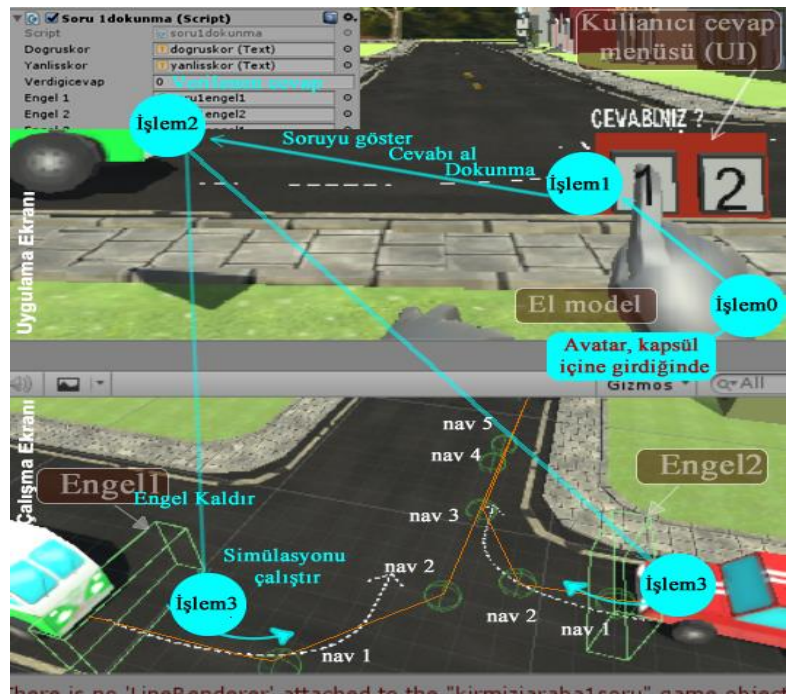

Şekil 8. T Kavşak senaryosu ve işlem adımları (T-junction scenario and process steps)

Şekil 9'da verilen T kavşak uygulamasındaki oyun yapay zekâ yapısına sahip araç hareket algoritmasının işlem adımları şu şekilde açıklanabilir:

\section{Hazırlı: Sorunun gizlenmesi ve araçların bekletilmesi}

İşlem 0: Avatar, kapsüle girdiğinde sorunun gösterilmesi

İşlem 1: Kullanıcı cevabının alınması ve iletilmesi (UI)

Işslem 2: Cevabın puanlanması ve sorunun gizlenmesi,

Işslem 3: Araçların kurala uygun hareket ettirilmesi 


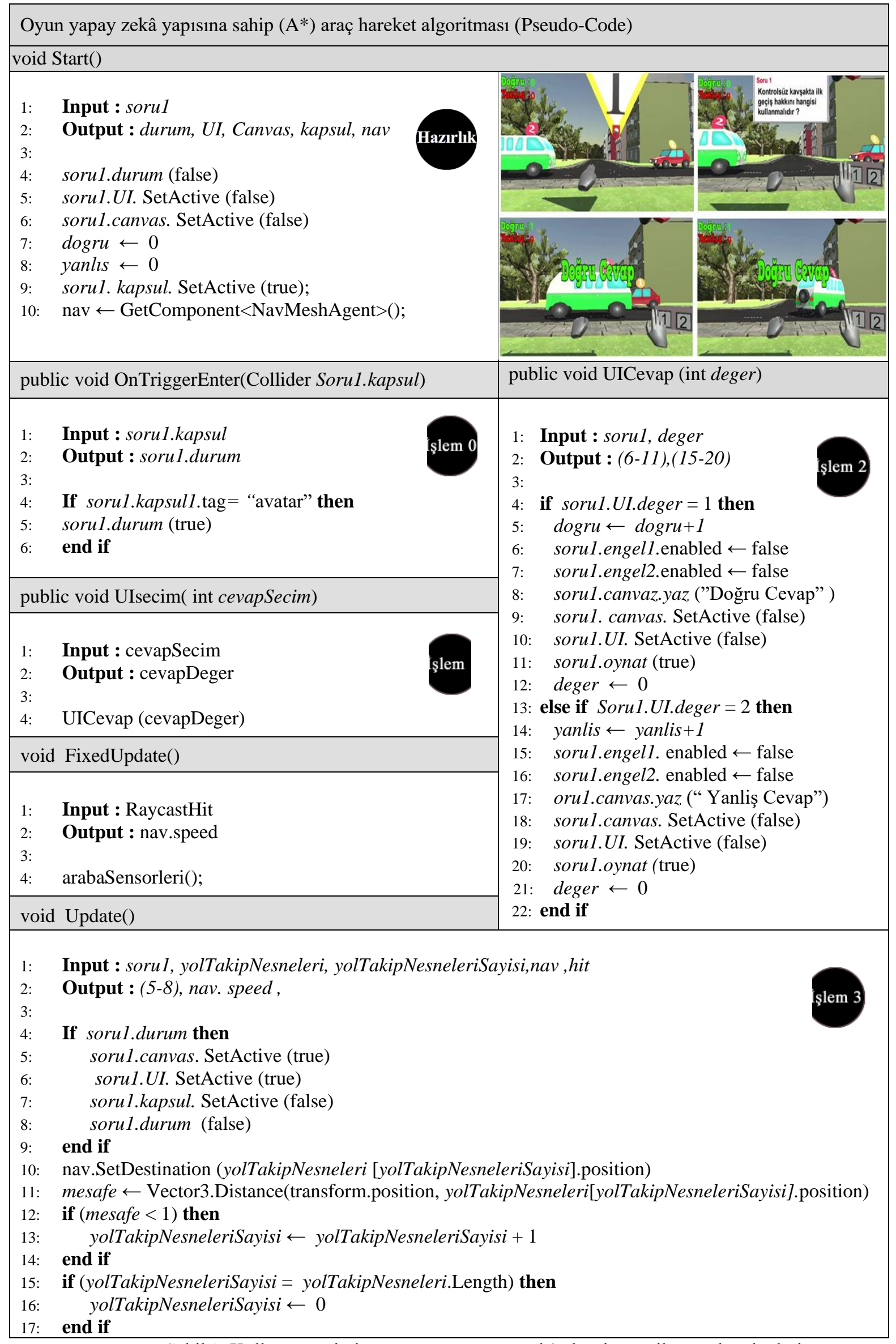

Şekil 9. Kullanıcı seçimi sonrası oyun yapay zekâ algoritması ile araç hareketleri (Vehicle movements with game AI algorithm after user selection) 
(b) Çarpışma kontrolleri: AI araçların çarpışma kontrolleri için RaycastHit sınıfı 1şınlar (rays) kullanılmıştır. Bu 1şınlar, bağlı olduğu nesnenin herhangi bir çarpıştırıcı veya diğer oyun nesneleri ile kesişip kesişmediğini belirlemek için kullanılır. Bu çalışmadaki amacı, sanal trafik ortamında yayanın, trafik 1 şık renginin veya başka bir AI aracının varlığını algılamaktır. Bu sayede AI araçlar önündeki veya kavşaktaki diğer araçlara yaklaşma durumunda hızını azaltma, yaya geçişlerinde yavaşlama veya kırmızı 1şıkta durma gibi zeki davranışlar sergilerler. Bu davranışlar AI araçları için çok önemlidir. Çünkü çevresi hakkında bilgisi olmayan bir AI aracı kırmızı 1şıkta durma, yaya geçidinde yaya/avatar için yavaşlama veya sağa ve sola dönüşlerde başka bir AI aracından kaçınma gibi işlemleri gerçekleştiremez. Belirtilen bu işlemler, Şekil 10'daki araç üzerindeki sensörlerden çıkan 1şınların nesnelere (araç, avatar ve trafik 1 şı bariyeri) temas etmesi yöntemiyle çözümlenmiştir.

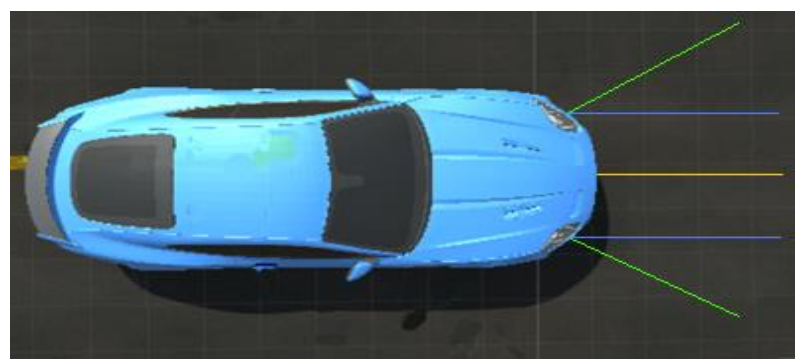

Şekil 10. Işınlar (Rays)

Temas sonrası alınan veriler (bool tipi) fizik tabanlı bir yaklaşım motoru kullanarak hesaplanmıştır. Elde edilen değerler AI araçlarının gerçekçi bir şekilde "Sürüş", "Yavaşlama" ve "Durma" durumlarında kullanılmıştır. Çalışmada, tüm AI araçlara çarpışma kontrol özelliğ kazandırmak için önce raycasthit sınıfına ilişkin tüm bilgilerin yazılacağı yeni bir komut dosyası oluşturulmuş ve bu komut dosyası AI araçlarına bağlanmıştır. Sonrasında komut dosyasına toplam 5 adet 1 şın (physics.raycast) belirli açı ve yönlerde tanımlanmıştır. $\mathrm{Bu}$ 1şınların AI araç modeli üzerindeki konumları Şekil 10 'da gösterilmiştir. Şekil 11 ise 1şınların kullanıldığ örnek uygulama görselleridir. Bu görsellerden soldaki trafik 1şığı olmayan bir yaya geçiş noktasındaki Avatar'ın geçişini, sağdaki kırmızı 1 şı uygulama noktasındaki araçların bekleme durumunu yansıtmaktadır.
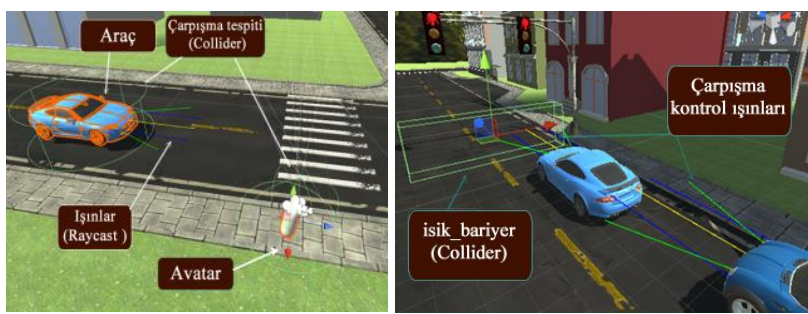

Şekil 11. Yaya geçişi ve 1şık durumu (Pedestrian access and light state)

(c) Trafik ışık durumları: Çalışmanın trafik 1şıkları için Sonlu Durum Makinesi (Finite States Machine, FSM) kullanılmıştır. Sonlu Durum Makinesi, bazı giriş parametrelerine dayanarak belirli durumlara geçiş yapan bir sistemdir. $\mathrm{Bu}$ sistem önceden belirlenmiş durumlar ve geçiş kümesinden oluşur. $\mathrm{Bu}$ çalışmada, trafik 1 şığ kırmızı, sarı ve yeşil olmak üzere üç duruma; ışık süresi ve ışık geçiş düğmesine dokunma olmak üzere iki geçiş koşuluna sahiptir. Bir çalışma durumdan diğerine geçiş, geçiş kümesindeki koşulların yerine getirilmesi ile tanımlanır [31]. Bu basit bir geçiş gibi görülmesine karşın isik_bariyer (engel) nesnesinin aktifliği ve AI araç hareketleri için son derece önemlidir. Çünkü kırmızı ve sarı 1şıkta araçların durmasını sağlayan isik_bariyer aktif nesne haline, yeşil 1şıkta araçların hareket etmesi için isik_bariyer pasif nesne haline geçer. Böylece; kırmızı 1şık durumunda AI aracı "Sürüş" durumundan "Yavaşlama" ve sonrasında "Durma" durumuna, yeşil 1şıkta araç "Sürüş" durumuna geçiş yapar. Bu geçiş, AI araç ışınlarının (raycast) isik_bariyer nesnesine teması üzerinden gerçekleşir. Şekil 12'de verilen resimlerden soldaki trafik ışık algoritmasını, sağdaki giriş sinyali t göz önüne alınmış trafik ışı̆̆ı Sonlu Durum Makinesi diyagramını yansitmaktadır.
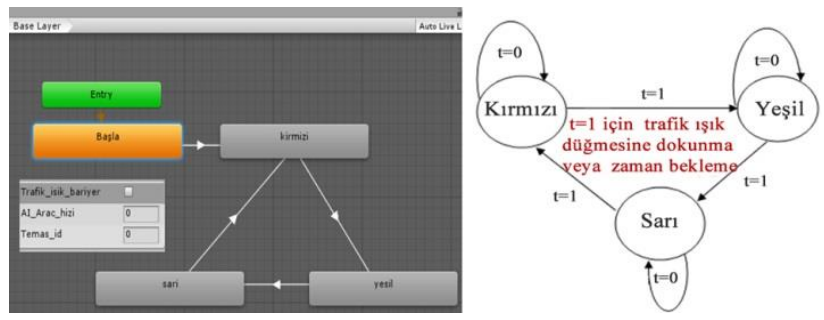

Şekil 12. Trafik sinyali için sonlu durum makinesi (Finite state machine for traffic signal)

\subsection{Oyunun Puanlanmasl (Scoring of Game)}

Kullanıcının bir Avatar ile temsil edildiği bu çalışmada, 5 kural sorusu, 5 uygulama sorusu ve 5 trafik işaret sorusu örnek soru olarak oluşturulmuştur. Kullanıcıya tüm soruların konumları uygulama arayüzün sol üst kısımda bulunan küçültülmüş bir soru haritası (mini-map) üzerinden işaretlemeler ile gösterilmiştir. Avatar bu sorulara gerçek el hareketleri ile şehir içerisinde dolaşarak ulaşmaktadır. Yine gerçek el hareketleri ile soruları cevaplamakta ve trafik ışığı ve yaya geçiş uygulamalarını gerçekleştirmektedir. Kullanıcının bu işlemleri yapması için bir süre kısıtlamasına gidilmemiş ancak süre takibi yapılmıştır. Arayüz ekranında kullanıcının doğru puanları şu durumlara göre güncellenerek gösterilmiştir:

- Seçimli sorulara doğru yanıt verildiğinde, 10 puan eklemek;

- Uygun trafik ışı̆̆ında geçildiğinde, 20 puan eklemek;

- Güvenli yaya geçiş uygulaması yapıldığında, 20 puan eklemek;

- Doru/yanlış şeklindeki trafik işaret levhası sorularına doğru yanıt verildiğinde, 10 puan eklemek.

Soruların yanlış cevaplanması ve yanlış uygulanması durumunda aynı ağırlıktaki puanlar yanlış puan olarak eklenmiştir. 


\subsection{Test ve Değerlendirme (Testing and Evaluation)}

Araştırmada, deneysel çalışma için nicel araştırma yöntemlerinden yarı deneysel desen kullanılmıştır. Seçilen yöntem ile katılımcılar, deney ve kontrol gruplarına rastgele atanmıştır. Araştırmanın öntest ve sontestini "Trafik Kuralları Başarı Testi” oluşturmuştur. Yapılan eğitim, deney grubunu temsil eden ortamda, geliştirilen uygulamanın yüklü VR gözlüğü ile gerçekleştirilmiş, kontrol grubunu temsil eden ortamda ise Trafik ve Çevre Bilgisi notları ile geleneksel öğretim yöntemi kullanılarak gerçekleştirilmiştir. Tüm çalışma 1 (bir) gün sürmüştür.

Araştırmanın evrenini, 18-25 yaş arasında sürücü ehliyeti olan, öğrenci olmayan, trafik bilgisi konularında zorluk yaşayan katılımcılar oluşturmuştur. Çalışmada örneklem yöntemi olarak "Olasılığa Dayalı Olmayan Örneklem" yöntemi kullanılmıştır. Araştırmanın örneklemini, kartopu yöntemi ile ulaşılan, 22 katılımcı oluşmaktadır. Örneklem işleminde; katılımcıların sağlık durumlarına, hafta sonu katılım isteklerine ve trafik bilgisi koşullarına bakılmıştır. $\mathrm{Bu}$ koşullar çerçevesinde 22 katılımcı rastgele deney (11 kişi) ve kontrol guruplarına (11 kişi) atanmıştır.

\subsection{Veri Toplama Aracl (Data Collection Instrument)}

Araştırmanın nicel bölümünde Başarl Testi ve Buradalık Anketi, nicel bölümünde ise Katılımcı Görüş Formu kullanılmıştır.

Başarı Testi: Alan uzmanları tarafından geliştirilen bir testtir. Kullanım amacı, uygulama aracının etkinliğini, verimliliğini ve katılımcıların başarı düzeylerini ölçmektir. Test öncesi trafik geçiş kurallarını, araç üstünlüklerini ve trafik işaret levhalarını konu edinen belirtke tablosu hazırlanmış ve kazanımlar dikkate alınarak 30 maddeden oluşan çoktan seçmeli test havuzu oluşturulmuştur. Test havuzundaki sorularının açıklığı, okunabilirlik ve kapsam geçerlilik bakımından incelenmiş, ekleme, çıkartma ve düzeltmeler sonucunda başarı testi 4 seçenekli 15 madde ile devam edilmiştir.

Buradalı Anketi: Katılımcıların sanal ortamda var olma (bulunma hissi) derecesi, VR kalitesi ve ortamı bireysel değerlendirme raporları ile ölçülmesidir. $\mathrm{Bu}$ çalışmada Witmer ve diğerleri (2005) [35] tarafından geliştirilen ve Gökoğlu ve Çakıroğlu (2019) [36] tarafindan Türkçeye uyarlaması yapılan Buradalık Anketi (Presence Questionnaire) kullanılmıştır.

Katılımcı Görüş Formu: Deney grubunun uygulama sonrası uygulamaya yönelik görüşlerini araştırma soruları doğrultusunda toplamak, memnuniyetlerini ölçmek amacıyla kullanılmıştır. Bu görüşme yer alan sorular şu şekildedir: Soru1: El hareket (kavrama, seçme, dokunma) işlemlerinde zorluk yaşadınız mı? Soru2: Uygulamayı kullanmak sizi nasıl etkiledi ve kullanırken neler hissettiniz? Soru3: Kullanmış olduğunuz uygulama trafik eğitiminde eğitim amaçlı kullanılabilir mi?
3.7. Geçerlik, Güvenilirlik ve Normallik (Validity, Reliability and Normality)

Başarı testi verilerinin güvenilirliği SPSS ile belirlenmiştir. Değerler; ortalama madde güçlük indeksi; 0,57, ortalama ayırt edicilik gücü indeksi; 0,42 ve KR-20 test güvenirliği; 0,69 olarak bulunmuştur. $\mathrm{Bu}$ sonuçlar testin geçerlilik ve güvenilirliği için yeterlidir.

Deney ve kontrol grup verilerine uygulanacak yöntem ve tekniğin belirlenmesi için normallik varsayımı yapılmıştır. Çalışmanın grup büyüklüğü 50'den küçük olduğu için Shapiro-Wilk testi kullanılmıştır [37]. Tablo 1'de deney ve kontrol gruplarının başarı testine ilişkin öntest, sontest ve fark değerlerine ait Shapiro-Wilk test sonuçları verilmiştir.

Tablo 1. Grupların Shapiro-Wilk normallik değerleri (Shapiro-Wilk normality test values of groups)

\begin{tabular}{|l|c|c|c|}
\hline \multicolumn{1}{|c|}{ Gruplar } & İstatistik & $\mathrm{df}$ & $\mathrm{p}$ \\
\hline Deney Öntest & 0,951 & 11 & 0,658 \\
\hline Deney Sontest & 0,970 & 11 & 0,890 \\
\hline Deney Fark Değerleri & 0,826 & 11 & 0,021 \\
\hline Kontrol Öntest & 0,946 & 11 & 0,590 \\
\hline Kontrol Sontest & 0,964 & 11 & 0,818 \\
\hline Kontrol Fark Değerleri & 0,950 & 11 & 0,647 \\
\hline
\end{tabular}

Tablo 1 incelendiğinde, her bir veri setinin anlamlılık düzeyinin 0,05 değerinden $(p>0,05)$ büyük olduğu görülmektedir. $\mathrm{Bu}$ durum deney ve kontrol gruplarına ait veri setlerinin normal dağılıma uyduğu söylenebilir. Tablo 2'de deney ve kontrol gruplarının başarı testine ilişkin öntest, sontest ve fark değerlerine ait basıklık ve çarpıklık ölçüleri verilmiştir

Tablo 2. Grupların çarpıklık ve basıklık değerleri (Kurtosis and skewness values of groups)

\begin{tabular}{|c|c|c|c|c|c|}
\hline Grup & Test & $\begin{array}{c}\text { Basıklık ve } \\
\text { Çarpıklık }\end{array}$ & Katsayı & S.Hata & $\begin{array}{c}\text { Katsayı / } \\
\text { S.Hata } \\
\end{array}$ \\
\hline \multirow{6}{*}{ 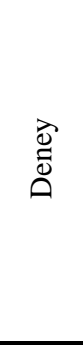 } & \multirow{2}{*}{ Öntest } & Çarpıklık & 0,225 & 0,661 & 0,340 \\
\hline & & Basıklık & $-0,865$ & 1,279 & $-0,676$ \\
\hline & \multirow{2}{*}{ Sontest } & Çarpıklık & $-0,493$ & 0,661 & $-0,745$ \\
\hline & & Basıklık & 0,106 & 1,279 & 0,082 \\
\hline & \multirow{2}{*}{$\begin{array}{l}\text { Fark } \\
\text { Değerleri }\end{array}$} & Çarpıklık & 0,767 & 0,661 & 1,160 \\
\hline & & Basıklık & $-0,035$ & 1,279 & $-0,027$ \\
\hline \multirow{6}{*}{$\begin{array}{l}\bar{O} \\
\stackrel{\Xi}{0} \\
\ddot{1}\end{array}$} & \multirow{2}{*}{ Öntest } & Çarpıklık & $-0,468$ & 0,661 & $-0,708$ \\
\hline & & Basıklık & $-0,652$ & 1,279 & $-0,509$ \\
\hline & \multirow{2}{*}{ Sontest } & Çarpıklık & 0,173 & 0,661 & 0,261 \\
\hline & & Basıklık & $-0,924$ & 1,279 & $-0,722$ \\
\hline & \multirow{2}{*}{$\begin{array}{l}\text { Fark } \\
\text { Değerleri }\end{array}$} & Çarpıklık & 0,040 & 0,661 & 0,060 \\
\hline & & Basıklık & $-0,840$ & 1,279 & $-0,656$ \\
\hline
\end{tabular}


Tablo 2 incelendiğinde, tüm çarpıklık ve basıklık katsayıları \pm 1 sınırları [38] içindedir. Z değerleri -1,96 ile $+1,96$ arasında $(0,05)$ görülmektedir. $\mathrm{Bu}$ değerler ile gruplara ait veri setinin normalliği kabul edilebilir, veri setine parametrik test (t-testi) uygulanabileceği söylenebilir.

\section{BULGULAR (FINDINGS)}

4.1. "Deney grubunun öntest ile sontest puanlarl arasında anlamlı bir fark var mıdır?" Araştırma Sorusuna Ait Bulgular (Is there a significant difference between pre-test and post-test scores of experimental group? Results of Research Question)

Araştırma sorusuna göre ilişkili örneklem t-testi sonuçları Tablo 3'de verilmiştir.

Tablo 3. Deney grubu başarı testi t testi sonuçları

(Sample t-test results of achievement test experimental group)

\begin{tabular}{|c|c|c|c|c|c|c|c|}
\hline Grup & Testler & $N$ & $\bar{X}$ & $S S$ & $t$ & $S d$ & $P$ \\
\hline \multirow{2}{*}{ Deney } & Öntest & 11 & 11,91 & 2,46 & & & \\
\cline { 2 - 8 } & Sontest & 11 & 15,18 & 2,60 & $-10,75$ & 10 & $0,000 *$ \\
\hline${ }^{*} \mathrm{p}<0,05$
\end{tabular}

Tablo 3 incelendiğinde, deney grubu öntest ortalama puanının X̄öntest $=11,91$, sontest ortalama puanının $\bar{X}_{\text {sontest }}=15,18$ olduğu görülmektedir. Deney grubu başarı testi öntest ve sontest ortalamaları arasında anlamlı bir fark bulunduğu ve bu farkın istatistiksel olarak anlamlı olduğu tespit edilmiştir [ $\mathrm{t}(10)=-10,75, \mathrm{p}<0,005]$. Deney grubunun ortalama değerleri karşılaştırıldığında sontest lehine anlamlı bir farkın olduğu görülmüştür. Ortalamalar arasındaki farkın etki büyüklüğü ise çok büyük düzeyde olduğu tespit edilmiştir (Cohen's d=1,29>0,80). Bu sonuçla, geliştirilen uygulama aracının katılımıı başarısını pozitif yönde etkilediği söylenebilir.

4.2. "Kontrol grubunun öntest ile sontest puanlarl arasında anlaml bir fark var mıdır?" Araştırma Sorusuna Ait Bulgular (Is there a significant difference between pre-test and post-test scores of the control group? Results of Research Question)

Araştırma sorusuna göre ilişkili örneklem t-testi sonuçları Tablo 4'de verilmişstir.

Tablo 4. Kontrol grubu başarı testi t testi sonuçları

\begin{tabular}{|c|c|c|c|c|c|c|c|}
\hline Grup & Testler & $N$ & $\bar{X}$ & $S S$ & $t$ & $S d$ & $P$ \\
\hline \multirow{3}{*}{ Kontrol } & Öntest & 11 & 11,55 & 1,96 & & & \\
\cline { 2 - 8 } & Sontest & 11 & 13,91 & 3,14 & $-3,18$ & 10 & $0,000 *$ \\
\hline
\end{tabular}

Tablo 4 incelendiğinde, kontrol grubu öntest ortalama puanının $\bar{X}$ öntest $=11,55$, sontest ortalama puanının $\overline{\mathrm{X}}$ sontest $=13,91$ olduğu görülmektedir. Kontrol grubu başarı testi öntest ve sontest ortalamaları arasında anlamlı bir fark bulunduğu ve bu farkın istatistiksel olarak anlamlı olduğu tespit edilmiştir $[\mathrm{t}(10)=-3,18, \mathrm{p}<0,005]$. Kontrol grubunun ortalama değerleri karşılaştırıldığında sontest lehine anlamlı bir farkın olduğu görülmüştür. Ortalamalar arasındaki farkın etki büyüklüğü ise büyük düzeyde olduğu tespit edilmiştir (Cohen's $\mathrm{d}=0,90>0,80$ ). Bu sonuçla, mevcut eğitim yönteminin katılımcı başarısını pozitif yönde etkilediği söylenebilir.

4.3. "Deney ve Kontrol gruplarının öntest ve sontest fark puanları arasında anlamlı bir fark var midır?” Araştırma Sorusuna Ait Bulgular (Is there a significant difference between pre-test and post-test difference scores of the experimental and control groups? Results of Research Question)

Araştırma sorusuna göre ilişkisiz örneklem t-testi sonuçları Tablo 5'de verilmiştir.

Tablo 5. Deney ve Kontrol gruplarının öntest sontest fark puanları sonuçları

(Results of pre-test and post-test difference scores of the experimental

\begin{tabular}{|l|c|c|c|c|c|c|}
\hline Grup & $N$ & $\bar{X}$ & $S S$ & $t$ & $S d$ & $P$ \\
\hline Deney & 11 & 3,27 & 1,00 & \multirow{2}{*}{1,28} & \multirow{2}{*}{20} & \multirow{2}{*}{$0,223^{*}$} \\
\cline { 1 - 4 } Kontrol & 11 & 2,18 & 2,63 & & & \\
\hline
\end{tabular}

$* \mathrm{p}<0,05$

Tablo 5 incelendiğinde, deney grubu fark puanları ortalamasının ( $\bar{X}$ deneyfark $=3,27$ ), kontrol grubu fark puanları ortalamasına ( $\bar{X}$ kontrolfark $=2,18)$ göre istatistiksel olarak anlamlı bir farklılık göstermediği ve deney grubu fark puanları ortalamasının kontrol grubu fark puanları ortalamasına göre yüksek olduğu tespit edilmiştir. İki grubun fark puanları ortalaması karşılaştırıldığında bu farkın deney grubu lehine olduğu söylenebilir. Ortalamalar arasındaki farkın etki büyüklüğü ise orta düzeyde olduğu tespit edilmiştir. $\mathrm{Bu}$ bulgu, mevcut eğitim yöntemi ile yapılan eğitime göre orta düzeyde etki büyüklüğüne sahip olduğu şeklinde yorumlanabilir.

4.4. "Fare/klavye ve el hareket arabirimi performans süreleri arasinda anlaml bir farkl var midır ?" Araştırma Sorusuna Ait Bulgular (Is there a significant difference between mouse/keyboard and hand tracking interface performance times? Results of Research Question)

Kullanılan el hareket izleme yönteminin performans1, fare/klavye (PC) ve el hareket arabirimleri arasında aynı soru noktalarına ulaşmak için geçen süre miktarları karşılaştırılarak değerlendirilmiştir. Değerlendirmeye 
geçmeden önce, gidilecek soru noktaları belirlenmiş, harita üzerinde gösterilmiş ve bu noktalara dokunma ile tetiklenen zamanlayıcı eklenmiştir. Çalışma için 5 kişilik iki grup oluşturulmuştur. İlk grup, uygulamayı masaüstü bilgisayarda fare/klavye ile uygulamış ve klavye/fare verileri üretilmiştir. İkinci grup, uygulamayı Oculus Rift üzerinden Leap Motion ile gerçekleştirmiş ve temassız el hareket verileri elde edilmiştir. Şekil 13'de görüleceği gibi fare/klavye $14,02 \pm 3,03$ ve el hareket izleme arabirimi $11,63 \pm 2,46$ ortalama değerleri bulunmuştur. Her iki oturumdan elde edilen verilere göre temassiz el hareket izleme arabirimin sanal ortam hareket süresi fare/klavye arabirimi sanal ortam hareket süresinden daha kısa olduğunu göstermiştir.

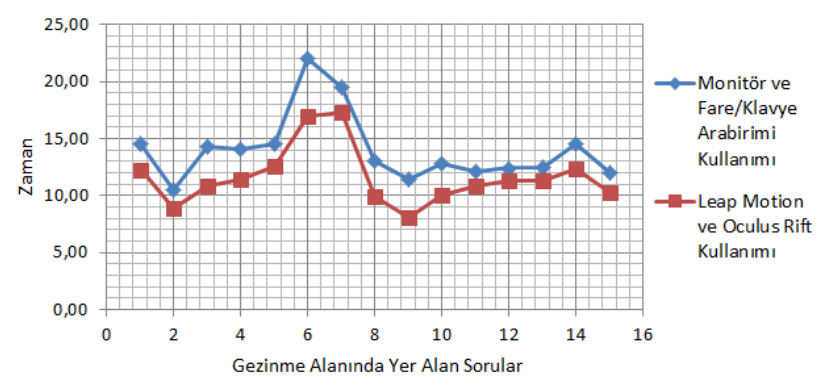

Şekil 13. Fare/klavye ve el hareket performans süreleri (Mouse and hand gesture performance times)

4.5. Deney grubunun sanal ĕgitim ortamındaki bulunma hissi düzeyi ne seviyededir?" Araştırma Sorusuna Ait Bulgular (What is the level of presence of the experimental group in virtual educational environment? Results of Research Question)

Deney grubuna Buradalık Anketi uzman eğitmenler eşliğinde uygulanmıştır. Ölçek 5'li likert tipinde ve 5 faktörü kapsamaktadır. Katılımcıların her bir faktöre ilişkin ortalama ve standart sapma değerleri Tablo 6' da verilmiştir.

Tablo 6. Deney grubu katılımciların bulunma hissi seviyeleri (Levels of sense of presence of experiment group

\begin{tabular}{|l|c|c|}
\multicolumn{1}{|c|}{ Farticipants $)$} \\
\hline Katılım & Ortalama $(\overline{\mathrm{X}})$ & Standart Sapma \\
\hline Duygusal Bağl1lık & 4,76 & 0,519 \\
\hline Uyum/Çevreleme & 4,80 & 0,516 \\
\hline Arayüz Kalitesi & 4,78 & 0,521 \\
\hline Etkileşim & 4,84 & 0,501 \\
\hline Toplam $(\mathrm{N}=11)$ & 4,91 & 0,515 \\
\hline
\end{tabular}

Tablo 6 incelendiğinde, anketinin bütününe ait ortalama değer $\bar{X}=4,81$ olarak bulunmuştur. $\mathrm{Bu}$ değer ankette "Çok Yüksek Düzey" ifadesine yakın gelmektedir. Bu ifadeye göre; geliştirilen uygulamanın katılımcıların dikkatlerini uyardığı (katılım), görsel, işitsel ve dokunsal his sağladığı (duygusal bağlılık), daldırma hissine (uyum/çevreleme) odakladığı, etkileşim ve kontrol arayüz (arayüz kalitesi) yapısının etkili olduğu şeklinde açıklanabilir.

4.6. "Deney grubunun geliştirilen eğitim aracına yönelik görüşleri nelerdir?” Araştırma Sorusuna Ait Bulgular (What are the options of the experimental group about developed education tool? Results of Research Question)

$\mathrm{Bu}$ bölümde görüşme formu ile yazılı alınan görüşlerin özetlenmiş hali yer almaktadır. Deney grubu katılımcılara; S1 başlıklı soru sorulduğunda; statik el hareket komutlarını hatırlamada ve gezinme işlemlerinde Avatarı hareket ettirmede zorlanmadıklarını, soru cevaplamalarını ve tutma eylemlerini kolaylıkla gerçekleştirebildiklerini belirtmişılerdir.

... el ile sanal ortamda rahatlikla dolaşabildim, soruları cevaplayabildim ve uygulamalarl gerçekleştirebildim. Klavye ve fare kullanmadan işlemeleri yapmak güzel ve yenilikçi...

S2 başlıklı soru sorulduğunda; uygulamanın yenilikçi olduğunu, uygulamayı kullanırken heyecanlandıklarını, soruları okurken cevaplandırırken ve uygularken eğlendiklerini ve öğrendiklerini, tekrar tekrar denemek istediklerini belirtmişlerdir.

...VR gözlügünü kullanırken heyecanlandım. İlk başta endişe ediyordum. Trafik sorularını okumak, doğru animasyonlarl görmek ve uygulamak çok ögreticiydi...

S3 başlıklı soru sorulduğunda; VR aracının kesinlikle kullanılması gerektiğini, trafik kuralları daha anlaşılır hale getirdiğini, etkileşimli olmasının öğreticiliği arttırdığını belirtmişlerdir. Ancak uzun kullanımlarda ellerin ve kolların yorulduğunu ifade etmişlerdir.

... trafik kurallar genellikle basılı kitap ve video gösterimi üzerinden ögretiliyor. Ancak kitap üzerinden yapılan ĕgitim ile VR uygulama ĕgitimi arasında büyük farklılıklar var. Bu ortam bize kaza riski ve yaşayarak ögrenme konusunda büyük firsatlar sunabilir...

\section{TARTIŞMA VE SONUÇ (DISCUSSION AND RESULT)}

$\mathrm{Bu}$ çalışmada, yayalara ve sürücü adaylarına trafik kuralarının eğitiminde sanal ortamların çözüm olup olmadığının belirlenmesine yönelik bir araştırma yürütülmüştür. Amaç, yayaların ve sürücü adaylarının trafik kurallarını ve işaretlerini öğrenebilmeleri için etkileşimli 3B ortam tasarlamaktır. $\mathrm{Bu}$ amaç için sanal trafik ortamı oluşturulmuş, farklı trafik kuralları farklı senaryolar şeklinde tasarlanmış, gezinme, kavrama, seçme ve dokunma işlemlerinde etkileşimli kullanıcı arayüzü 
kullanılmış ve geliştirilen eğitim yöntemi VR gözlüğünde uygulanmıştır.

Çalışmada, deney grubu sontest (X ${ }_{\text {sontest }}=15,18$ ) ortalama puanlarının öntest $((\overline{\mathrm{X}}=$ öntest $=11,91)$ ortalama puanlarından yüksek, bu farkın istatistiksel olarak anlamlı $[\mathrm{t}(10)=-10,75, \mathrm{p}<0,005]$ ve ortalamalar arasındaki farkın etki büyüklüğü ise çok büyük düzeyde olduğu tespit edilmiştir. Deney grubu sontest puanlarının yüksek olmasının sebebi; 3B sanal ortamların görsel, simülasyon ve uygulama eğitimlerini desteklemesi [31], kullanıcısına sanal ortamda bulunma hissi sağlaması [29], sürükleyici ve gerçekçi bir ortam sunması [23] ve yeni bir etkileşim teknolojisini temel alması olabilir. Ayrıca elde edilen etki büyüklüğü; sanal ortamların geleneksel eğitimden farkl bir sunuş ve etkileşim yaklaşımı içermesi, bu yaklaşımın VR gözlükleri üzerinden (ilgi, istek ve dikkat çekerek) gerçekleştirilmesi ve bilişsel ve algısal becerisinin olumlu yönde etkilemesi [22] ile açıklanabilir.

Çalışmada, kontrol grubu sontest $(\overline{\mathrm{X}}=$ sontest $=13,91)$ ortalama puanlarının öntest $(\overline{\mathrm{X}}=$ öntest $=11,55)$ ortalama puanlarından yüksek, bu farkın istatistiksel olarak anlamlı [t(10)=-3,18, p<0,005] ve ortalamalar arasındaki farkın etki büyüklüğü ise büyük düzeyde olduğu tespit edilmiştir. $\mathrm{Bu}$ etki büyüklüğünün sebebi; kullanıcıların geleneksel eğitim modeli ile öğrenme alışkanlıklarından ve bu modelde yer alan basılı (kitap) ve görsel (video) materyallerin erişim ve kullanım kolaylığından [31] kaynaklı olduğu düşünülmektedir.

Çalışmada, deney grubu fark puanları ortalamasının ( $\bar{X}$ deneyfark $=3,27$ ), kontrol grubu fark puanları ortalamasına ( $\overline{\mathrm{X}}$ kontrolfark $=2,18)$ göre istatistiksel olarak anlamlı bir farklılık göstermemesine karşın, deney grubu fark puanları ortalamasının kontrol grubu fark puanları ortalamasına göre yüksek olduğu tespit edilmiştir. İstatistiksel olarak anlamlı bir farklılık göstermemesinin nedeni; örneklem sayısının az olması olabilir. $\mathrm{Bu}$ çalışmada, örneklem sayısının artırılması anlamlılık düzeyini yükselteceği ve çalışmanın etkinliğini daha net ortaya çıkartacağı tahmin edilmektedir.

Deney grubu Buradalık Anketi bulgularına göre; ankette en yüksek ortalama değer faktörü Etkileşim $(\overline{\mathrm{X}}=4,91)$ bulunmuştur. $\mathrm{Bu}$ değerle birlikte bunu Arayüz Kalitesi $(\overline{\mathrm{X}}=4,84)$, Duygusal Bağlılık $(\overline{\mathrm{X}}==4,80)$, Uyum/Çevreleme $(\bar{X}==4,78)$ ve Katılım $(\bar{X}==4,76)$ faktörleri takip etmiştir. Etkileşim ve Arayüz kalitesi; uygulamanın kontrol ve görsel arayüz yapısını temsil eder. Diğer faktörlere göre Etkileşim değerinin fazla olması, çalışmada klavye ve fare gibi ortam hareketlerini kisıtlayacak araçlar yerine el davranışını analiz etmeyi sağlayan Leap Motion araç kullanımından [33], VR gözlük aracının etkin, verimli ve tatmin edici görüntü kalitesinden ve kullanım (hareket, dokunma, kavrama) kolaylığından [33] kaynaklı olduğu düşünülmektedir. Ancak uzun süreli VR gözlük kullanımının göz sağlığına verdiği olumsuz etkiler unutulmamalıdır [39]. Ayrıca etkileşim için ellerin sürekli havada kalması kas ağrılarına sebep olduğu göz ardı edilmemelidir. Diğer faktör Duygusal Bağlılık; uygulamanın görsel ve işitsel yapısını temsil eder. Sanal ortamların en önemli özelliklerinden birisi kullanıcıya seslerin, nesnelerin ve derinlik hissinin yüksek seviyeli sunulmasıdır. $\mathrm{Bu}$ anlamda çalışmada duygusal bağlılık değerinin yüksek bulunması; sabit derinlik yerine değişken derinlik sağlayan görüntüle aracı (VR gözlük) kullanımı, ortam seslerinin (araç, çocuk) varlığı [23] ve sanal çevrenin serbest gezilebilmesi [19] ile açıklanabilir. Ancak duygusal bağlılık hala bu çalışma için mükemmel değildir. Çünkü yüksek performans gerektiren farklı trafik kural simülasyonlarının uygulamaya eklenmesi ekran yenileme hızı, bellek kapasitesi ve işlemci yükü gibi donanımsal sorunları ortaya çıkartabilir. Araştırmada yüksek bulunan bir diğer faktör Uyum/Çevreleme; kullanıcının uygulama olaylarına, fiziksel etkileşimlere ve sanal çevreye uyumuna olan yaklaşımını ifade eder. $\mathrm{Bu}$ faktörün yüksekliği; kullanıcının geliştirilen sanal ortamdaki olayları korkuları olmadan yaşaması [21], sanal nesnelere dokunması ve gözü kaplayan VR aracının daldırma etkisini yaşaması ile açıklanabilir. Aynı zamanda kullanıcının sanal dünyayı tüm duyuları (görme, dokunma, duyma) ile tecrübe edebilmesi ve nesne etkileşimini doğal el hareketleri ile yapabilmesi [33] gibi durumlarla da açıklanabilir. Son faktör katılım; kullanıcının dikkatini uygulamaya vermesine yönelik soruları içerir. $\mathrm{Bu}$ faktör sonuçları; geliştirilen sanal ortamı kullanıcıların kullanma konusunda istekli olduğunu ifade etmektedir. Bu istek; geliştirilen ortamın kullanıcıların eğitim ve öğretim ihtiyaçlarına karşılık gelmesiyle [40] ve bu ortamı kullanmaktan memnun kalmalarıyla açıklanabilir. Genel olarak elde edilen bulgular, kullanıcıların ihtiyaçlarına ve hedeflerine statik görseller (kitap) ve tek yönlü materyallerin (video) kullanıldığı eğitim araçları yerine çift yönlü, etkileşimli [41] ve eğlenceli 3B eğitim ortamlarının ve araçlarının kullanılmasının daha güvenli [42] motive edici ve eğitici [43] olduğu sonucunu ortaya çıkartmış olabilir.

Görüşmede; kullanıcıların \%90`1 geliştirilen eğitim aracını kullanışlı, eğlenceli ve eğitici bulduklarını ifade etmişlerdir. Bu durum, çalışmanın Oculus Rift, doğal el davranışı [33] ve oyun tabanlı bir yaklaşım [44] kullanılmasından kaynaklandığı düşünülmektedir. Ancak bazı kullanıcılar el yorgunluğu [45] yaşadıklarını ifade etmişlerdir. Bunun nedeni Leap Motion cihazının etkileşim alanı için ellerin sürekli havada olmasından, 
Leap Motion cihazının Yakınlık (Hover Zone) ve Temas Bölgesinin (Touch Zone) geniş tutulmasından kaynaklandığı düşünülmektedir.

Bu sonuçların ardından çalışmanın sınırlılıkları şu şekilde tespit edilmiştir:

- El takibi için kullanılan Leap Motion cihazı uygun olmayan 1şık koşullarında el hareketlerini algılayamamıştır. Pozlama sebebiyle oluşan bu problem el hareketlerinin sanal el modeline iletilememesine neden olmuş, gerçek el ile el modeli arasındaki etkileşimi sınırlandırmıştır.

- Oculus Rift cihazının Windows 7 ve Windows 8.1 desteği olmadı için uygulama Windows 10 üzerinde çalıştırılmıştır. Windows 10, çalışmanın masaüstü işletim sistemi sınırlamasını oluşturmuştur.

- $\mathrm{Bu}$ çalışma, az sayıdaki örneklemle yapılmıştır. Daha güçlü bulgular elde etmek için örneklem sayısının artırılması gerekmektedir.

Bu doğrultuda, araştırmacılara gelecekteki çalışmalar için aşağıdaki öneriler verilebilir:

- Küresel salgınların (covid-19) yer aldığı bir dünyada VR ortamlar uzaktan yapılan sanal eğitimlerde kullanılabilir ve kullanıcılarına güvenli bir eğitim ortamı sunabilir.

- Günümüzde gerçek el tabanlı VR gözlüklerin (Oculus Quest 2) beşinci nesil (5G) iletişim sistemleri ile kullanılması, yakın gelecekte bulut tabanlı VR ortamları etkili bir uygulama alanı haline getirebilir.

- Sanal Gerçeklik ile biyometrik kimlik doğrulama ve yapay zekâ ile desteklenmiş etkileşim yöntemleri, yazarın gelecekteki çalışma planları arasında yer almaktadır ve araştırmacıların bu alanlara yönelik çalışmalar yapmaları önerilmektedir.

\section{ETIKK BEYAN ( ETHICAL STATEMENT)}

Yazar bu çalışmanın etik kurul izni veya yasal-özel bir izin gerektirmediğini beyan eder.

\section{KAYNAKLAR (REFERENCES)}

[1] V. Sönmez, "Okul Öncesi ve Temel Eğitimde Trafik Eğitiminin Önemi”, 1. Trafik Şurası Bildiriler Kitabı, EGM Trafik Daire Başkanlığı Ankara, 392-393, 1991.

[2] M. Peden, R. Scurfeld, World Report on Road Traffic Injury Prevention, Geneva: World Health Organization, 2004.

[3] Ş. Yaprak, A. M. Akbulut, Trafik kaza ve denetim istatistikleri, Polis Akademisi Yayınları, Ankara, (2019).
[4] J. D. Demetre, D. N. Lee, T. K. Pitcairn, R. Grieve, J.A. Thomson, K. Ampofo-Boateng, "Errors in young children's decisions about traffic gaps: Experiments with roadside simulations", British Journal of Psychology, 83(2), 189-202, 1992.

[5] Y. C. Rivas, P.A. V. Valdivieso, M. A. Y. Rodriguez, "Virtual reality and 21st-century education", International Research Journal of Management, IT and Social Sciences, 7(1), 37-44, 2020.

[6] G. Varinlioğlu, G. Alankuş, A. Aslankan, G. Mura, "Oyun Tabanlı Öğrenme ile Dijital Mirasın Yaygınlaştırılması", METU Journal of the Faculty of Architecture, 36(1), 23-40, 2019.

[7] K. Seaborn, D. Fels, "Gamification in theory and action: A survey", International Journal of Human-Computer Studies, 74, 14-31.

[8] Z. Gökkaya, "Yetişkin Eğitiminde Yeni Bir Yaklaşım: Oyunlaştırma", HAYEF: Journal of Education, 11,71-84, 2014.

[9] J. Hamari, "Transforming Homo Economicus into Homo Ludens: A Field Experiment on Gamification in a Utilitarian Peer-To-Peer Trading Service", Electronic Commerce Research and Applications, 12(4), 236-245, 2013.

[10] D.Kamińska, T. Sapiński, S. Wiak, T. Tikk, R. E. Haamer, E. Avots, A. Helmi, C. Ozcinar and G. Anbarjafari, "Virtual Reality and Its Applications in Education: Survey", Information, 10(10), 318, 2019.

[11] G. C. Burdea, P. Coiffet, Virtual Reality Technology, Wiley: Hoboken, USA, 2003.

[12] M. Roussou, "Immersive interactive virtual reality in the museum", Trends in Leisure Entertainment, 2001.

[13] O. Bamodu, X. Ye, "Virtual reality and virtual reality system components", Advanced Materials Research, 765, 1169-1172, 2013.

[14] F. P. C. M. De Jong, H. Van Der Meijden and J. Von Berg, “3D learning in the workplace and at school: playing, learning, or both? “, Educational Technology, 45(5), 30-34, 2005.

[15] J. C. Servotte, M. Goosse, S. H. Campbell S. H. Et al., "Virtual Reality Experience: Immersion, Sense of Presence, and Cybersickness", Clinical Simulation in Nursing, 38, 35-43, 2020.

[16] A. Tzanavari, S. Matsentidou, C. G. Christou and C. Poullis, "User experience observations on factors that affect performance in a road-crossing training application for children using the CAVE", International Conference on Learning and Collaboration Technologies, Greece, 91-101, 2014.

[17] O. Bart, N. Katz, P. L. Weiss and N. Josman, "Street crossing by typically developed children in real and virtual Environments", OTJR: Occupation, Participation and Health, 28(2), 89-96, 2008.

[18] P. Maillot, A. Dommes, N. T. Dang and F. Vienne, "Training the elderly in pedestrian safety: transfer effect between two virtual reality simulation devices", Accident Analysis \& Prevention, 99, 161-170, 2017.

[19] B. A. Morrongiello, M. Corbett, J. Beer and S. Koutsoulianos, "A pilot randomized controlled trial testing the effectiveness of a pedestrian training program that teaches children where and how to cross the street safely", Journal of Pediatric Psychology, 43(10), 1147-1159, 2018. 
[20] D. C. Schwebel, J. Gaines, J. Severson, "Validation of virtual reality as a tool to understand and prevent child pedestrian injury", Accident Analysis \& Prevention, 40(4), 1394-1400, 2008

[21] I. T. Feldstein, G. N. Dyszak, "Road crossing decisions in real and virtual environments: A comparative study on simulator validity", Accident Analysis \& Prevention, 137, 105356, 2020

[22] D. C. Schwebel, L. A. McClure, "Using virtual reality to train children in safe street-crossing skills", Injury Prevention, 16(1), 2010 .

[23] Y. Zhao, C. L. Bennett, H. Benko, E. Cutrell, C. Holz, M. R. Morris and M. Sinclair, "Enabling People with Visual Impairments to Navigate Virtual Reality with a Haptic and Auditory Cane Simulation”, 2018 CHI Conference on Human Factors in Computing Systems, Canada, 1-14, 2018.

[24] N. Murphy, Virtual Reality as Navigation Tool: Creating Interactive Environments For Individuals With Visual Impairments, Master's Theses, Kennesaw State University Science Computer Science, 2018.

[25] S. Parsons, S. Cobb, "State-of-the-art of virtual reality technologies for children on the autism spectrum", European Journal of Special Needs Education, 26(3), 355-366, 2011.

[26] S. L. Lee and C. Y. Huang, "The effects of 3-D graphic-based virtual reality on the pedestrainized skills for elementary students with intellectual disabilities", 18th Asian Conference on Mental Retardation, Taipei, Taiwan, 2007.

[27] T. A. Clancy, J. J. Rucklidge, D. Owen, "Road-crossing safety in virtual reality: A comparison of adolescents with and without ADHD”. Journal of Clinical Child \& Adolescent Psychology, 35(2), 203-215, 2006

[28] Y. K. Oua, Y. C. Liub, C. H. Linc, "Investigation of Roadcrossing Safety Before and After Training for patient with Parkinson's disease", 19th Triennial Congress of the IEA Melbourne, Australia, 9, 14, 2015.

[29] B. Liu, Z. Wang, G. Song, G. Wu, "Cognitive processing of traffic signs in immersive virtual reality environment: An ERP study”, Neuroscience Letters, 485(1), 43-48, 2010.

[30] A. D. Lukito, R. Sanjaya, H. Prasetya, "Virtual Reality Game Education to Learn Traffic Regulation", SISFORMA: Journal of Information Systems (e-Journal), 4(1), 7-11, 2017

[31] C. Proaño, C. Villacís, V. Proaño, W. Fuertes, M. Almache, M Zambrano and F. Galárraga, "Serious 3D Game over a Cluster Computing for Situated Learning of Traffic Signals", 2019 IEEE/ACM 23rd International Symposium on Distributed Simulation and Real Time Applications (DS-RT) , Italy, 1-10, 2019.
[32] K. A. Şen, K. Nikbay ve B. T. Akgün, "Sürücüsüz Araç Trafiğ ile Sürücü Davranışı İyileştirmeye Yönelik Bir Oyun: OKANOM”, Eleco 2014, Türkiye, 371-375, 2014.

[33] L. Shao, Hand movement and gesture recognition using Leap Motion Controller, Virtual Reality, Course Report, 2016.

[34] A. K. Guruji, H. Agarwal, D. K. Parsediya, "Time-efficient A* algorithm for robot path planning, Procedia Technology, 23, 144 149, 2016.

[35] B. G. Witmer, C. J. Jerome, M. J. Singer, "The factor structure of the presence questionnaire". Teleoperators \&Virtual Environments, 14(3), 298-312, 2005.

[36] S. Gökoğlu, Ü. Çakıroğlu, "Sanal Gerçeklik Temelli Öğrenme Ortamlarında Bulunuşluk Hissinin Ölçülmesi: Bulunuşluk Ölçeğinin Türkçe’ye Uyarlanması”, Eğitim Teknolojisi Kuram ve Uygulama, 9(1), 169-188, 2019.

[37] Ş. Büyüköztürk, Sosyal Bilimler İçin Veri Analizi El Kitabı: İstatistik, Araștırma Deseni, SPSS Uygulamaları ve Yorum, Pegem A Yayıncılık, 40, Ankara, 2007.

[38] B. G. Tabachnick, L. S. Fidell, Using Multivariate Statistics,5, United States: Pearson Education, Boston, 2013.

[39] T. İçten, G. Bal, “Artırılmış gerçeklik üzerine son gelişmelerin ve uygulamaların incelenmesi", Gazi Üniversitesi Fen Bilimleri Dergisi Part C: Tasarım ve Teknoloji, 5(2), 111-136, 2017.

[40] T. İçten, G. Bal, “Artırılmış gerçeklik teknolojisi üzerine yapılan akademik çalışmaların içerik analizi”, Bilişim Teknolojileri Dergisi, 10(4), 401-415, 2017.

[41] H. Zare, S. Niknami, A. Heidarnia, M. H. Fallah, "Traffic safety education for child pedestrians: A randomized controlled trial with active learning approach to develop street-crossing behaviors", Transportation Research Part F: Traffic Psychology and Behaviour, 60, 734-742, 2019.

[42] C. V. Zegeer, M. Bushell, "Pedestrian crash trends and potential countermeasures from around the world", Accident Analysis \& Prevention, 44(1), 3-11, 2012.

[43] A. Meir, T. Oron-Gilad, Y. Parmet, "Are child-pedestrians able to identify hazardous traffic situations? Measuring their abilities in a virtual reality environment", Safety Science, 80, 33-40, 2015.

[44] G. Su, N. Li, Y. Yildiz, A. Girard, I. Kolmanovsky, "A traffic simulation model with interactive drivers and high-fidelity car dynamics", IFAC-PapersOnLine, 51(34), 384-389, 2019

[45] R. Huang, C. Harris-Adamson, D. Odell, D. Rempel, "Design of finger gestures for locomotionin virtual reality", Virtual Reality \& Intelligent Hardware, 1(1), 1-9, 2019. 